\title{
Influence of ohmic heating in the composition of extracts from Gracilaria vermiculophylla
}

\author{
Sara G. Pereira ${ }^{\mathrm{a}, 1}$, Catarina Teixeira-Guedes ${ }^{\mathrm{a}, 1}$, Gabriela Souza-Matos ${ }^{\mathrm{a}}$, Élia Maricato ${ }^{\mathrm{b}}$, \\ Cláudia Nunes $^{\mathrm{b}, \mathrm{c}}$, Manuel A. Coimbra ${ }^{\mathrm{b}}$, José A. Teixeira ${ }^{\mathrm{a}}$, Ricardo N. Pereira ${ }^{\mathrm{a}}$, Cristina M. \\ R. Rocha ${ }^{\text {a,* }}$ \\ ${ }^{\text {a }}$ Centre of Biological Engineering, University of Minho, Braga, Portugal \\ ${ }^{\mathrm{b}}$ LAQV-REQUIMTE, Department of Chemistry, University of Aveiro, 3810-193 Aveiro, Portugal \\ ${ }^{\mathrm{c}}$ CICECO, Department of Chemistry, University of Aveiro, 3810-193 Aveiro, Portugal
}

\section{A R T I C L E I N F O}

\section{Keywords:}

Gracilaria

Red seaweeds

Ohmic heating

Extraction

Agar

Biocompounds

\begin{abstract}
A B S T R A C T
Electric field-based technologies for extraction processes have been gaining importance due to sustainability concerns. This work aims to assess the potential of ohmic heating as an efficient and feasible tool for the extraction of different biocompounds from Gracilaria vermiculophylla and its effect on the extracts' composition. Different ratios of water/ethanol ( 0 to $75 \%$ ethanol, $v / v$ ) were used to target different families of biocompounds. The ohmic heating-based extraction was performed at $82{ }^{\circ} \mathrm{C}$ under electric field and frequency of $2-8 \mathrm{~V} / \mathrm{cm}$ and $25 \mathrm{kHz}$, respectively. Conventional extractions without the presence of electric field were made keeping a temperature profile identical to the ohmic heating treatments, thus addressing the potential occurrence of electrical (non-thermal) effects. Extraction yields and extracts composition (content in polysaccharides, proteins, phenolic compounds and pigments) were evaluated. Further, as agar is the major commertially exploited compound from Gracilaria spp., the effect of ohmic heating on the extracted agar in terms of yield, carbohydrates' composition, monosaccharides profile, and gelling ability was also envisaged.

Overall, significant differences in the extraction of each family of compounds between ohmic and conventional extractions were observed, being more pronounced at the best solvent for each compound (100\% water for carbohydrates, 75:25 water/ethanol for proteins, 75:25 and 50:50 water/ethanol for phenolic compounds and 25:75 water/ethanol for pigments). Higher extraction yields were achieved for ohmic heating at $1 \mathrm{~h}$, except for $100 \%$ water, probably indicating accelerated extraction kinetics promoted by the presence of electric field effects. Furthermore, the gelling ability of agar and the antioxidant activity were not impaired by the use of moderate electric fields. Therefore, ohmic heating is an interesting alternative, with reduced energy consumption and improved extraction performances, to recover functional ingredients or additives from seaweeds for the food industry.
\end{abstract}

\section{Introduction}

Marine ecosystem are extremely rich in natural resources, providing a wide variety of organisms, most of which still unexplored, including marine algae [1,2]. Seaweeds, which are photosynthetic autotrophic organisms, have been widely used in the hydrocolloids, pharmaceutical, cosmetic, fertilizers, feed, food, biorefineries and water treatment industries [3,4].

Seaweeds are classified based on the types of pigments they use for photosynthesis as Chlorophyta (green algae), Rhodophyta (red algae) and Phaeophyta (brown algae) [3,5]. The red seaweed Gracilaria spp. is a stress-tolerant species well adapted to different environmental factors, such as salinity variation, nutrient limitation, turbidity and low light availability [6]. It is originated from Japan but it has been established in Europe as an invasive species $[1,7,8]$. Gracilaria spp. have high carbohydrate (32-71\%) and ash content (3.6-53.4\%) but low amounts of protein (6.2-13\%) [9-12] and lipids (1-3\%) [13]. The presence of minerals in seaweeds is very important since they have several human

\footnotetext{
* Corresponding author at: Centre of Biological Engineering, University of Minho, Campus de Gualtar, 4710-057 Braga, Portugal.

E-mail address: cmrochainv@gmail.com (C.M.R. Rocha).

1 Sara G. Pereira and Catarina Teixeira-Guedes contributed equally to this work.
} 
nutritional functions. Pigments have also a positive impact on oxidation, being used as an anti-inflammatory and as wound healing agent $[14,15]$. Phycobilins are the main photosynthetic pigments present in red algae and they have gained special significance in many different sectors, such as food, pharmaceutical, and cosmetic due to their antioxidant and antitumoral activities [16].

These species have commercial importance due to its high content in agar that is present in the cell wall and intercellular spaces. Agar is composed of two polysaccharides, agarose (gel-forming component), with a linear chain of repeating units of $(1,3)$-linked- $\beta$-D-galactose and (1,4)-linked-3,6-anhydro- $\alpha$-L-galactose, and agaropectin, a branched polymer. It is a food additive used as a stabilizer, gelling agent and texture and viscosity enhancer, being a common ingredient in processed foods, including fruit jellies, dairy products, canned meats, soups, confectionery and baked goods and icings $[3,17]$.

The commercial agar extraction from seaweeds involves several steps such as washing and drying, aqueous extraction by heating, filtration to separate agar from the residues, freeze-thawing method, washing and bleaching [18,19]. Depending on the seaweed, there are some differences when it came to pre-treatment. In case of Gracilaria, it must be treated with alkali prior to extraction, to convert L-galactose-6sulfate units to 3,6-anhydro-L-galactose, resulting in an increment on the agar strength. The aqueous extraction could be performed using autoclave or water bath at boiling point. There are several factors that can affect the extraction of agar, including alkali concentration, extraction temperature and treatment duration. For Gracilaria species, the conditions described to produce agar with higher gel strengths include alkali concentrations between 3 and $10 \%\left(\mathrm{w} / \mathrm{v}\right.$ ) at $85-90{ }^{\circ} \mathrm{C}$ for $3.5 \mathrm{~h}$, followed by a weak acid to neutralize any residual alkali and extraction times ranging from 0.5 to $3 \mathrm{~h}$ at high temperatures of 80 to $90{ }^{\circ} \mathrm{C}[18,19]$. These extraction processes of the fraction of seaweeds are generally time consuming, require high solvent and energy consumptions and generate large amounts of waste. Therefore, the search for other eco-friendly and sustainable extraction methods has boosted due to the increasing ecological concerns. These methods could reduce or avoid the use of organic solvents (e.g.: ethanol, acetone, acetic acid, among others), reduce the extraction times, increase the extraction yields and improve the quality of seaweed-derived compounds [20]. The industry generates several byproducts from agar extraction procedures that could be used in a biorefinery perspective, such as, sugars extraction, production of bioethanol, used in animal feed and as biofertilizer $[21,22]$.

Ohmic heating $(\mathrm{OH})$ is based on the passage of an electric field through materials with the purpose of heating them uniformly and rapidly $[23,24]$. This technology allows an accurate temperature set while can also induce significantly membrane permeabilization and electroporation of cellular tissues, as enhancing the diffusion of molecules into vegetable tissues, drying, pasteurization and extraction of bioactive compound [24-27].

The aim of this work was to assess the feasibility of using $\mathrm{OH}$-assisted extraction in the selective recovery of different fractions from Gracilaria vermiculophylla. Water or mixtures with different ratios of water and ethanol were used as selective solvents with an affinity for different interest compounds such as carbohydrates, proteins, phenolic compounds and pigments. Specific aims included studying the effect of $\mathrm{OH}$ with moderate electric fields in the chemical profile of these different extracts from G. vermiculophylla. Furthermore, the influence of the $\mathrm{OH}$ process in the bioactive and technological properties of the extracts was also evaluated, which included the antioxidant activity and gel strength, aiming at a final application of the extracts as food additives, either with texturizing (e.g. gelling, in the case of agar-rich extracts) or antioxidant features. Thermal extractions without the presence of electric field were made to compare $\mathrm{OH}$ and conventional extraction (CE), using an indirect heating system (i.e. conventional heating) with temperature control, which allowed to keep an identical temperature profile of $\mathrm{OH}$ treatments, and thus address the occurrence of electrical (non-thermal) effects.

\section{Material and methods}

\subsection{Sampling and chemicals}

G. vermiculophylla was collected in the summer of 2018. The seaweed was provided by AlgaPlus (Ílhavo, Portugal), under standardized conditions, where it was selected, washed to remove epiphytes, sand and debris, dried at $60{ }^{\circ} \mathrm{C}$ and stored in sealed bags.

The following chemical reagents and standards were purchased from Sigma-Aldrich (St. Louis, MO, USA): 2,2-azino-bis(3-ethylbenzothiazoline)-6 sulphonic acid (ABTS), 2,4,6-Tripyridyl-s-Triazine (TPTZ), bovine serum albumin (BSA), gallic acid (GA), 6-hydroxy-2,5,7,8-tetremethychroman-2-carboxylic acid (Trolox), commercial agar (ash 2.0-4.5\%), glucose, rhamnose, mannose, galactose, fucose, ribose, 3,6anhydrogalactose, xylose, 2-deoxyglucose and galacturonic acid. All other chemicals used were of analytical grade.

\subsection{Chemical characterization of Gracilaria vermiculophylla}

Lipid, protein, ash and carbohydrate content of the seaweed were determined and expressed in percentage of dry weight of seaweed. The lipids content was assessed by Bligh-Dyer method [28] and the protein content by Kjeldahl method [29], using a conversion factor of 4.59 [30]. Ashes content were determined following NREL protocols (NREL/TP510-42,618).

The sugars composition (rhamnose, fucose, ribose, 3,6-anhydrogalactose, xylose, 6-O-metil-galactose, 4-O-metil-galactose, mannose, galactose, glucose, uronic acids) was determined by derivatization to alditol acetates and analyzed by GC-FID (Clarus 400, Perkin-Elmer, Waltham, MA, USA) after acid reductive hydrolysis [31] and the acidic sugars (uronic acids) were determined by the colorimetric method with $m$-phenylphenol [32]. The results were expressed as mol\%.

\subsection{Conventional and ohmic heating extraction}

The OH extraction of $G$. vermiculophylla seaweed was performed with $100 \%$ water and three different ratios of water/ethanol (75:25; 50:50; $25: 75, v: v)$ in a reactor of $500 \mathrm{~mL}$ with solid:solvent ratio of $1: 30$ for a final volume of $250 \mathrm{~mL}$. Two stainless steel electrodes were positioned approximately $8 \mathrm{~cm}$ apart from each other inside the glass reactor. The frequency and electric field were set at $25 \mathrm{kHz}$ and $2-8 \mathrm{~V} / \mathrm{cm}$, respectively, and the extraction was maintained for $1 \mathrm{~h}$ and $2 \mathrm{~h}$ at $82{ }^{\circ} \mathrm{C}$ under magnetic stirring [19]. The CE was performed using a water bath, under the same conditions, but without applying an electric field. The extraction processes were carried out in triplicate for each solvent ratio. The hot mixture obtained from each extraction procedure was filtered using a cotton filter cloth and then frozen at $-20^{\circ} \mathrm{C}$. Further characterization performed on the extract was carried out in triplicate.

\subsection{Extracts characterization}

\subsubsection{Carbohydrate content}

Carbohydrate content was determined by the method of PhenolSulfuric Acid according to Wang et al. [33] with minor modifications. For 96 -well plate, $50 \mu \mathrm{L}$ of sample or standard were added, followed by $150 \mu \mathrm{L}$ of sulfuric acid (96\%) and $30 \mu \mathrm{L}$ of phenol $\left(5 \%\right.$ in $\left.\mathrm{H}_{2} \mathrm{O}\right)$. The plates were incubated in the dark at $60{ }^{\circ} \mathrm{C}$ with stirring at $120 \mathrm{rpm}$ for 1 $\mathrm{h}$ and the absorbance was read at $490 \mathrm{~nm}$ in a microplate reader BIOTEK SYNERGY HT (Germany). Glucose was used as a standard (0.025-1.00 $\mathrm{mg} / \mathrm{mL}$ ). Results were expressed in $\mathrm{mg}$ of glucose equivalent per $\mathrm{g}$ of dry weight (DW) of seaweed and per $g$ of extract (mg glucose Eq./g DW).

\subsubsection{Protein content}

Protein content was assessed by the Lowry method [34], optimized 
for microplates, using BSA as standard (125-2500 $\mu \mathrm{g} / \mathrm{mL})$. Briefly, $20 \mu \mathrm{L}$ of blank, samples or standard were added to the plate followed by $200 \mu \mathrm{L}$ of Lowry's solution and $20 \mu \mathrm{L}$ of Folin-Ciocalteau. The plate was incubated for $4 \mathrm{~h}$ at $42{ }^{\circ} \mathrm{C}$ with stirring $(180 \mathrm{rpm})$ and the absorbance was read at $750 \mathrm{~nm}$ after $10 \mathrm{~s}$ of shaking. Results were expressed in $\mathrm{mg}$ of BSA equivalent per $g$ of dry weight of seaweed and per $g$ of extract (mg BSA Eq./g DW).

\subsubsection{Total phenolic content}

Total phenolic content was determined by the Folin-Ciocalteau method described by Teixeira-Guedes et al. [35]. In brief, $20 \mu \mathrm{L}$ of samples or GA standard (5-200 mg/L) were added, followed by $100 \mu \mathrm{L}$ of Folin-Ciocalteau solution (1:10 in water) and $80 \mu \mathrm{L}$ of sodium carbonate $\left(7.5 \%\right.$ in water). The reaction was incubated for $30 \mathrm{~min}$ at $42{ }^{\circ} \mathrm{C}$ in the dark and the absorbance measured at $750 \mathrm{~nm}$. Results were calculated using a standard curve and expressed as $\mathrm{mg}$ of gallic acid equivalents per $g$ of dry weight of seaweed and per $g$ of extract (mg GA Eq./g DW).

\subsubsection{Photosynthetic pigments}

Photosynthetic pigments were quantified by spectrophotometric measurement using a UV-VIS spectrophotometer JASCO V-560 (Germany), considering mainly pigments adsorbing in the ranges of chlorophylls and carotenoids according to Lichtenthaler et al. [36]. The absorbances were read at wavelengths 664.1, 648.6 and $470 \mathrm{~nm}$. Quantification of pigments was calculated using the following formulas:

Chlorophyll $\mathrm{a}=(13.36 \times$ Abs $664.1-5.19 \times$ Abs 648.6$)$

Chlorophyll $\mathrm{b}=(27.43 \times$ Abs $648.6-8.12 \times$ Abs 664.1$)$

Total carotenoids $=((1000 \times$ Abs $470-2.13 \times \mathrm{cl} \mathrm{a}-97.64 \times \mathrm{cl} \mathrm{b}) / 209)$

Results were expressed as mg of equivalent pigment per $g$ of dry weight of seaweed and per $\mathrm{g}$ of extract (mg/g DW).

\subsubsection{Antioxidant activity}

Ferric reducing antioxidant power (FRAP) assay was performed according to Bolanos de la Torre et al. [37]. Previously the FRAP working solution was prepared by mixing 10-volumes of acetate buffer (300 $\mathrm{mM}$ ), 1-volume of TPTZ (10 mM of TPTZ in $40 \mathrm{mM}$ of hydrochloric acid) and 1-volume of iron (III) chloride ( $20 \mathrm{mM}$ in water). To the 96 -well plate $20 \mu \mathrm{L}$ of sample or Trolox standard was added followed by 280 $\mu \mathrm{L}$ of FRAP working solution. The reaction was incubated at $37{ }^{\circ} \mathrm{C}$ in the dark for $30 \mathrm{~min}$ and read at $593 \mathrm{~nm}$.

ABTS radical scavenging assay was determined as described by Teixeira-Guedes et al. [35]. To assess ABTS, $12 \mu \mathrm{L}$ of sample or standard and $188 \mu \mathrm{L}$ of ABTS working solution were pipetted into 96-well plate. The plate was incubated at room temperature for $30 \mathrm{~min}$ in the dark and then the absorbance was measured at $734 \mathrm{~nm}$. ABTS solution ( $7 \mathrm{mM}$ ) was prepared in distilled water and the radical was established using a solution of potassium persulfate $(148 \mathrm{mM})$. The mixture was maintained at room temperature protected from the light for 12 to $16 \mathrm{~h}$. To prepare the ABTS working solution, the radical was diluted in $20 \mathrm{mM}$ of acetate buffer and the observance was set at 0.7 to $734 \mathrm{~nm}$. The $\%$ of inhibition was calculated using the following formula: $\%$ inhibition $=($ Abs blank Abs sample) / Abs blank x 100. The antioxidant capacity was determined based on interpolation of the calibration curve for Trolox. The results were expressed in $\mathrm{mM}$ Trolox equivalent per $\mathrm{g}$ of extract.

\subsection{Agar-enriched fraction recovery}

These seaweeds are naturally rich in agar, which, when present in sufficient amount, separates from the solution upon freezing and thawing procedure. Therefore, for the frozen samples, the agar-enriched fraction (the main soluble polysaccharide from Gracilaria sp.) was recovered through a freeze-thawing process whenever as possible [19].
For the $75: 25 ; 50: 50 ; 25: 75$ water/ethanol ratios, the syneresis water was removed by centrifugation in a Heraeus Multifuge X3R centrifuge (USA) $(7000 \times g$ for $10 \mathrm{~min})$. For $100 \%$ water solvent, the agar-enriched fraction separates naturally, and no centrifugation was needed. The agar-enriched fractions (centrifuged or naturally separated) were dehydrated with ethanol (96\%) and dried overnight at $60{ }^{\circ} \mathrm{C}$. Further characterizations were performed on the agar-enriched fraction in triplicate.

\subsection{Agar-enriched fraction characterization}

\subsubsection{Carbohydrate content and monosaccharide profile}

Carbohydrate content was determined as described above in Section 2.4.1. Results were expressed in $\mathrm{mg}$ of glucose equivalent per $\mathrm{g}$ of agarenriched fraction (mg glucose Eq./g DW). The sugars profile was determined by GC-FID, as described above in Section 2.2. and the results were expressed as the content in mass (mg) of each sugar present per $g$ of agar-enriched fraction obtained.

\subsubsection{Agar structure}

Functional groups (sulfate groups) and bonding arrangement of constituents present in the agar-enriched fraction $(\mathrm{OH}$ and $\mathrm{CE}$ with $100 \%$ water for $2 \mathrm{~h}$ ) were determined by Fourier Transform Infrared Spectroscopy (FTIR) using an ALPHA II- Bruker spectrometer (Ettlingen, Germany) with a diamond-composite attenuated total reflectance (ATR) cell. The FTIR spectra were recorded in the range of $4000-400 \mathrm{~cm}^{-1}$, by acquiring 64 scans cycles per samples with $4 \mathrm{~cm}^{-1}$ resolution. Analyses were carried out in triplicate.

\subsubsection{Gel strength}

Gel strength was determined as described by Villanueva et al. [19] using a texture analyzer TA.HDplus from Stable Micro Systems (England) equipped with a cylindrical probe with $10 \mathrm{~mm}$ of diameter. Agarenriched fraction $(1.5 \% \mathrm{w} / \mathrm{w}, 0.225 \mathrm{~g})$ was milled with a coffee grinder $(150 \mathrm{~W})$ and solubilized in boiling distilled water until complete solubilization. The hot solutions ( $15 \mathrm{~g}$ ) were transferred into a cylindrical container with $30 \mathrm{~mm}$ of diameter and kept at room temperature for 20 h. The rate of penetration used was $0.2 \mathrm{~mm} / \mathrm{s}$. Gel strength was considered to be the stress required to break the gel surface. Results were expressed in $\mathrm{g}$ per $\mathrm{cm}^{2}$. As control, the gel strength of commercial agar) was determined in the same conditions presenting a gel strength of 612 $\mathrm{g} / \mathrm{cm}^{2}$.

\subsection{Technologies comparison for agar extraction using an alkali pre- treatment}

For the best agar extraction condition according to extraction yields and gel strengths, $2 \mathrm{~h}$ of extraction and $100 \%$ water, a comparison between technologies (OH and $\mathrm{CE}$ ), with pre-treated seaweed was performed. The seaweed was pre-treated by an alkali treatment with $\mathrm{NaOH}$ $6 \%(w / w)$, at a solid:solvent ratio of 1:30 for a final volume of $250 \mathrm{~mL}$, at $85{ }^{\circ} \mathrm{C}$ for $3.5 \mathrm{~h}$. After that, the seaweed was washed several times with tap water and neutralized with acetic acid $0.5 \%(\mathrm{w} / \mathrm{w})$ at room temperature for $1 \mathrm{~h}$. Prior to the extraction, the conductivity was adjusted to $1 \mathrm{mS} / \mathrm{cm}$. The extraction conditions of $\mathrm{OH}$ and $\mathrm{CE}$ were previously described in Section 2.3. [19] Agar-enriched fraction was purified by heat solubilization at $0.2 \%(\mathrm{w} / \mathrm{w})$ followed by centrifugation $\left(40{ }^{\circ} \mathrm{C}\right.$, $16500 \times g$ for $1 \mathrm{~h}$ ) and dried at $60{ }^{\circ} \mathrm{C}$. The extraction yields and gel strength before and after the purification step were evaluated.

\subsection{Statistical analysis}

Statistical analysis was performed using IBM SPSS Statistics 25.0 software (SPSS Inc., Chicago, IL, USA). Two-way analysis of variance (ANOVA) followed by Tukey's multiple comparisons tests was used to compared different groups. A $p$ value $<0.05$ was considered statistically 
significant.

\section{Results and discussion}

In this study a comparison between ohmic heating $(\mathrm{OH})$ assisted extraction and conventional extraction (CE) was performed in terms of their effect on the composition of the extracts from G. vermiculophylla. The solvents used for extraction of biocompounds were selected according to safety and environmental concerns (ethanol and water are approved food grade solvents) [38]. Extracts with different compositions were achieved when using different ratios of water/ethanol. Further, whenever possible, an enriched fraction in agar was separated from the extract and analyzed. Results are expressed in terms of yield of the crude extract relating to the dry weight of seaweed and extract composition. Yield, composition, monosaccharide profile and gelling ability are presented for the refined agar-enriched fraction.

\subsection{Chemical characterization of Gracilaria vermiculophylla}

The results of seaweed chemical characterization are shown in Table 1. G. vermiculophylla displayed a lipid content of $1.58 \pm 0.11 \%$, protein content of $14.7 \pm 0.04 \%$, an ash content of $25.5 \pm 2.17 \%$, and a carbohydrate content of $49.5 \pm 0.78 \%$. These results are in accordance with the literature [9-11,13]. The composition in sugars was also analyzed and G. vermiculophylla was composed mainly by galactose (34 mol\%), 3,6-anhydrogalactose (24 $\mathrm{mol} \%$ ), and glucose (19 $\mathrm{mol} \%)$, as expected due to the typical content in agar and cellulose. Small amounts of other monosaccharides were also observed, including fucose, ribose, xylose, methylated sugars such as 4-O-metil-galactose and 6-O-metilgalactose and uronic acids (less than $10 \mathrm{~mol} \%$ ). The chemical composition in sugars obtained in this work is in agreement with previous reports and is characteristic of Gracilaria spp. [39,40]. However, it is known that the chemical composition of the seaweed is dependent on several environmental conditions and can vary significantly along the seasons, depending on temperature and place of cultivation [30].

\subsection{Extracts characterization}

\subsubsection{Total extraction yield}

The effect of $\mathrm{OH}$ and $\mathrm{CE}$ on the total extraction yield of the extracts (dry weight) using different solvent ratios of water and ethanol at $1 \mathrm{~h}$ and $2 \mathrm{~h}$ of extraction is shown in Table 2 . Total extraction yield ranged from 22 to $43 \%$ in both $\mathrm{OH}$ and CE. Both extraction methods displayed higher yield using $100 \%$ water (38-43\%) and decrease when ethanol percentage increases, 75:25 water/ethanol (33-35\%), 50:50 water/ ethanol (28-34\%) and 25:75 water/ethanol (22-26\%). Overall, $2 \mathrm{~h}$ showed a higher extraction yield when compared to $1 \mathrm{~h}$, whereas the ratio of 25:75 water/ethanol using $\mathrm{OH}$ had no significant differences. Similar extraction yields were observed when comparing both technologies at $2 \mathrm{~h}$ of extraction.

\subsubsection{Carbohydrate}

The carbohydrate content in the different extracts (mg per g extract) is presented in Table 3. In 25:75 water/ethanol solvent ratio, the carbohydrate content ranged from 160 to $247 \mathrm{mg} / \mathrm{g}$ and increased with the water content until 643 to $766 \mathrm{mg} / \mathrm{g}$ in $100 \%$ water (approximated values). For $100 \%$ water solvent, $2 \mathrm{~h}$ of extraction showed higher

Table 1

Seaweed chemical characterization expressed in percentage (\%) of dry weight.

\begin{tabular}{llll}
\hline Gracilaria & & \\
\hline Lipid & Protein & Ash & Carbohydrate \\
\hline $1.58 \pm 0.11$ & $14.7 \pm 0.04$ & $25.5 \pm 2.17$ & $49.5 \pm 0.78$ \\
\hline
\end{tabular}

Data presented as mean \pm standard deviation.
Table 2

Effect of ohmic heating and conventional extraction on the total extraction yield expressed in $\%$ of different solvent ratio at $1 \mathrm{~h}$ and $2 \mathrm{~h}$ of extraction.

\begin{tabular}{llllll}
\hline \multirow{2}{*}{$\begin{array}{l}\mathrm{H}_{2} \mathrm{O} / \text { EtOH } \\
\text { v) }\end{array}$} & \multicolumn{2}{l}{ Ohmic heating } & & \multicolumn{2}{l}{ Conventional extraction } \\
\cline { 2 - 3 } \cline { 5 - 6 } & $1 \mathrm{~h}$ & $2 \mathrm{~h}$ & & $1 \mathrm{~h}$ & $2 \mathrm{~h}$ \\
\hline $100: 0$ & $38.8 \pm$ & $43.0 \pm$ & & $38.6 \pm$ & $41.6 \pm$ \\
& $1.31^{\mathrm{dA}}$ & $0.40^{\mathrm{dB}}$ & & $0.43^{\mathrm{dA}}$ & $0.06^{\mathrm{dB}}$ \\
$75: 25$ & $34.6 \pm$ & $35.2 \pm$ & & $33.1 \pm$ & $35.3 \pm$ \\
& $0.36^{\mathrm{cB}}$ & $0.12^{\mathrm{cC}}$ & & $0.01^{\mathrm{cA}}$ & $0.22^{\mathrm{cC}}$ \\
$50: 50$ & $30.8 \pm$ & $32.9 \pm$ & & $28.1 \pm$ & $33.7 \pm$ \\
& $0.06^{\mathrm{bB}}$ & $0.48^{\mathrm{bC}}$ & & $0.41^{\mathrm{bA}}$ & $0.68^{\mathrm{bC}}$ \\
$25: 75$ & $25.2 \pm$ & $25.7 \pm$ & & $21.8 \pm$ & $25.4 \pm$ \\
& $0.17^{\mathrm{aB}}$ & $0.52^{\mathrm{aB}}$ & & $1.98^{\mathrm{aA}}$ & $0.64^{\mathrm{aB}}$ \\
\hline
\end{tabular}

Data presented as mean \pm standard deviation from three replicates. The data marked by the same letters were not significantly different $(p>0.05)$. Different lowercase letters for comparison within solvents and uppercase letters for comparison within extraction technologies, indicating significant differences $(p$ $<0.05)$.

carbohydrate content in comparison to $1 \mathrm{~h}$. Overall, $\mathrm{OH}$ had more carbohydrates content than CE, with an increase of $7 \%$ and $26 \%$, using $100 \%$ water and 75:25 water/ethanol at $2 \mathrm{~h}$, respectively.

The extraction yield in carbohydrate (mg per $\mathrm{g}$ seaweed) is presented in Table 4. In 25:75 water/ethanol solvent ratio, the yield in carbohydrate ranged from 11 to $13 \mathrm{mg} / \mathrm{g}$ DW and increased with the water content until 101 to $140 \mathrm{mg} / \mathrm{g}$ DW in $100 \%$ water (approximated values). Overall, $2 \mathrm{~h}$ of extraction showed higher yield in carbohydrate in comparison to $1 \mathrm{~h}$, except for the 25:75 water/ethanol solvent ratio. $\mathrm{OH}$ extraction using $100 \%$ water and 75:25 water/ethanol at $2 \mathrm{~h}$, resulted in an increase of $11 \%$ and $26 \%$ in carbohydrate yield, respectively, when compared with $\mathrm{CE}$. A positive correlation between yield in carbohydrate and the percentage of the water used for extraction was also observed with significant differences among solvents $(p<0.05)$.

Extraction using $100 \%$ water as a solvent brought much more efficiency in the carbohydrate extraction than other ratios of water/ethanol because polar solvents, like water, can extract polar compounds such as carbohydrates [38], as seen in Tables 3 and 4.

\subsubsection{Protein}

The effect of $\mathrm{OH}$ and $\mathrm{CE}$ on the protein content (mg per $\mathrm{g}$ extract) using a different ratio of water and ethanol is shown in Table 3. The solvent ratio $50: 50$ water/ethanol $(310-478 \mathrm{mg} / \mathrm{g}$ ) had better ability for protein extraction compared to 75:25 water/ethanol $(289-405 \mathrm{mg} / \mathrm{g}$ ), $25: 75$ water/ethanol (278-416 mg/g) and $100 \%$ water $(132-156 \mathrm{mg} / \mathrm{g}$ ), values shown in decreasing order (approximated values). $\mathrm{OH}$ using 50:50 water/ethanol solvent, showed an increase of approximately $30 \%$ of protein content at $1 \mathrm{~h}$ when compared to $2 \mathrm{~h}$ of extraction, and, using 75:25 water/ethanol solvent, $\mathrm{OH}$ showed an increase of approximately 9 and $22 \%$ at $1 \mathrm{~h}$ and $2 \mathrm{~h}$, respectively, when compared to CE.

The effect of $\mathrm{OH}$ and $\mathrm{CE}$ on the yield in protein (mg per $\mathrm{g}$ seaweed) is shown in Table 4. The solvent ratio 75:25 water/ethanol (49-76 mg/g DW) had better ability for protein extraction when compared to 50:50 water/ethanol (46-61 mg/g DW), 25:75 water/ethanol (30-38 mg/g DW) and $100 \%$ water (27-30 mg/g DW), values shown in decreasing order (approximated values). Comparing times of extraction, treatments of $1 \mathrm{~h}$ presented higher protein extraction when compared to $2 \mathrm{~h}$, being this increase significant in 75:25 water/ethanol solvent using both technologies and in 50:50 water/ethanol solvent but only for $\mathrm{OH}$. $\mathrm{OH}$ using 75:25 water/ethanol solvent, showed an increase of approximately 17 and $23 \%$ of protein yield, at $1 \mathrm{~h}$ and $2 \mathrm{~h}$, respectively when compared to $\mathrm{CE}$. In general, $\mathrm{OH}$ presented higher capability of protein extraction particularly using 75:25 water/ethanol and 50:50 water/ ethanol.

Proteins extraction from seaweeds is a complex process, they are highly cohesive with polysaccharides, allocated on a highly rigid and structural cell wall, mostly in an insoluble form. Based on this, the 
Table 3

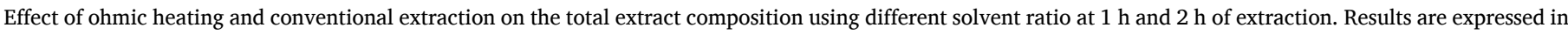
mg per $g$ of extract.

\begin{tabular}{|c|c|c|c|c|c|c|}
\hline & $\begin{array}{l}\mathrm{H}_{2} \mathrm{O}: \\
\text { EtOH }\end{array}$ & $\begin{array}{l}\text { Carbohydrate content (mg Glc Eq./ } \\
\text { g) }\end{array}$ & $\begin{array}{l}\text { Protein } \\
\text { content } \\
\text { (mg BSA Eq./ } \\
\text { g) }\end{array}$ & $\begin{array}{l}\text { Total phenolic } \\
\text { content } \\
\text { (mg GA Eq./g) }\end{array}$ & $\begin{array}{l}\text { Total chlorophylls } \\
\text { content } \\
(\mathrm{mg} / \mathrm{g})\end{array}$ & $\begin{array}{l}\text { Total carotenoids } \\
\text { content } \\
(\mathrm{mg} / \mathrm{g})\end{array}$ \\
\hline \multirow{3}{*}{ Ohmic heating } & & Extraction $1 \mathrm{~h}$ & & & & \\
\hline & 100:0 & $737 \pm 46.0^{\mathrm{cB}}$ & $156 \pm 7.86^{\mathrm{aB}}$ & $6.88 \pm 0.34^{\mathrm{aA}}$ & $0.02 \pm 0.01^{\mathrm{aA}}$ & $0.01 \pm 0.01^{\mathrm{aAB}}$ \\
\hline & $75: 25$ & $408 \pm 27.7^{\mathrm{bAB}}$ & $405 \pm 31.1^{\mathrm{cB}}$ & $9.99 \pm 0.36^{\mathrm{bA}}$ & $0.03 \pm 0.01^{\mathrm{aA}}$ & $0.01 \pm 0.00^{\mathrm{aA}}$ \\
\hline \multirow{6}{*}{$\begin{array}{l}\text { Conventional } \\
\text { extraction }\end{array}$} & $50: 50$ & $361 \pm 28.1^{\mathrm{bA}}$ & $478 \pm 15.4^{\mathrm{dB}}$ & $13.5 \pm 1.04^{\mathrm{cA}}$ & $0.18 \pm 0.02^{\mathrm{bA}}$ & $0.07 \pm 0.01^{\mathrm{bA}}$ \\
\hline & $25: 75$ & $247 \pm 1.55^{\mathrm{aC}}$ & $278 \pm 15.4^{\mathrm{bA}}$ & $15.9 \pm 0.65^{\mathrm{dB}}$ & $4.26 \pm 0.54^{\mathrm{cB}}$ & $0.79 \pm 0.09^{\mathrm{cC}}$ \\
\hline & 100:0 & $643 \pm 45.0^{\mathrm{cA}}$ & $138 \pm 8.73^{\mathrm{aAB}}$ & $7.39 \pm 0.09^{\mathrm{aA}}$ & $0.01 \pm 0.00^{\mathrm{aA}}$ & $0.01 \pm 0.00^{\mathrm{aA}}$ \\
\hline & $75: 25$ & $383 \pm 34.7^{\mathrm{bAB}}$ & $371 \pm 16.6^{\mathrm{bB}}$ & $9.94 \pm 0.45^{\mathrm{bA}}$ & $0.04 \pm 0.00^{\mathrm{bA}}$ & $0.02 \pm 0.00^{\mathrm{bB}}$ \\
\hline & $50: 50$ & $378 \pm 13.8^{\mathrm{bA}}$ & $443 \pm 19.6^{\mathrm{cB}}$ & $13.0 \pm 0.22^{\mathrm{cA}}$ & $0.22 \pm 0.05^{\mathrm{cC}}$ & $0.09 \pm 0.02^{\mathrm{cA}}$ \\
\hline & $25: 75$ & $216 \pm 10.9^{\mathrm{aB}}$ & $416 \pm 13.5^{\mathrm{cB}}$ & $15.9 \pm 0.43^{\mathrm{dB}}$ & $1.89 \pm 0.30^{\mathrm{dA}}$ & $0.47 \pm 0.07^{\mathrm{dAB}}$ \\
\hline \multirow{3}{*}{ Ohmic heating } & & Extraction $2 \mathrm{~h}$ & & & & \\
\hline & 100:0 & $766 \pm 1.60^{\mathrm{cB}}$ & $132 \pm 8.81^{\mathrm{aA}}$ & $8.24 \pm 0.45^{\mathrm{aB}}$ & $0.01 \pm 0.00^{\mathrm{aA}}$ & $0.01 \pm 0.00^{\mathrm{aA}}$ \\
\hline & $75: 25$ & $454 \pm 59.4^{\mathrm{bB}}$ & $354 \pm 14.2^{\mathrm{cB}}$ & $11.5 \pm 1.07^{\mathrm{aB}}$ & $0.05 \pm 0.00^{\mathrm{bB}}$ & $0.04 \pm 0.00^{\mathrm{bC}}$ \\
\hline \multirow{6}{*}{$\begin{array}{l}\text { Conventional } \\
\text { extraction }\end{array}$} & $50: 50$ & $361 \pm 41.7^{\mathrm{bA}}$ & $342 \pm 16.6^{\mathrm{cA}}$ & $12.6 \pm 0.47^{\mathrm{aA}}$ & $0.18 \pm 0.01^{\mathrm{cA}}$ & $0.07 \pm 0.00^{\mathrm{cA}}$ \\
\hline & $25: 75$ & $191 \pm 18.5^{\mathrm{aB}}$ & $278 \pm 4.05^{\mathrm{bA}}$ & $13.5 \pm 0.68^{\mathrm{aA}}$ & $1.95 \pm 0.08^{\mathrm{dA}}$ & $0.39 \pm 0.01^{\mathrm{dA}}$ \\
\hline & 100:0 & $716 \pm 23.5^{\mathrm{cAB}}$ & $141 \pm 8.86^{\mathrm{aAB}}$ & $7.33 \pm 0.31^{\mathrm{aA}}$ & $0.03 \pm 0.01^{\mathrm{aA}}$ & $0.02 \pm 0.00^{\mathrm{aB}}$ \\
\hline & $75: 25$ & $332 \pm 26.4^{\mathrm{bA}}$ & $289 \pm 17.8^{\mathrm{bA}}$ & $9.68 \pm 0.19^{\mathrm{bA}}$ & $0.03 \pm 0.00^{\mathrm{aA}}$ & $0.02 \pm 0.00^{\mathrm{aB}}$ \\
\hline & $50: 50$ & $348 \pm 15.3^{\mathrm{bA}}$ & $310 \pm 12.8^{\mathrm{cA}}$ & $11.9 \pm 0.43^{\mathrm{cA}}$ & $0.19 \pm 0.01^{\mathrm{bB}}$ & $0.07 \pm 0.00^{\mathrm{bA}}$ \\
\hline & $25: 75$ & $160 \pm 5.54^{\mathrm{aA}}$ & $306 \pm 16.3^{\mathrm{cA}}$ & $12.4 \pm 1.40^{\mathrm{cA}}$ & $2.54 \pm 0.24^{\mathrm{cA}}$ & $0.51 \pm 0.03^{\mathrm{cB}}$ \\
\hline
\end{tabular}

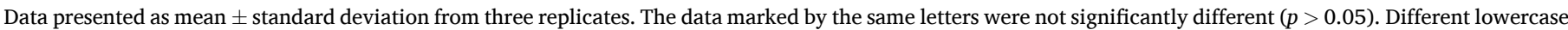

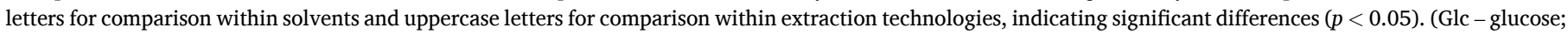
BSA - bovine serum albumin; GA - gallic acid).

Table 4

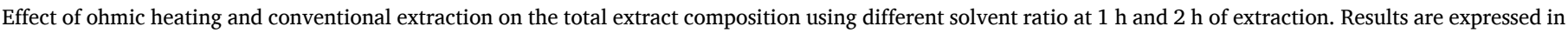
mg per $g$ dry weight of seaweed.

\begin{tabular}{|c|c|c|c|c|c|c|}
\hline & $\begin{array}{l}\mathrm{H}_{2} \mathrm{O}: \\
\text { EtOH }\end{array}$ & $\begin{array}{l}\text { Carbohydrate content (mg Glc Eq./ } \\
\text { g) }\end{array}$ & $\begin{array}{l}\text { Protein } \\
\text { content } \\
\text { (mg BSA Eq./ } \\
\text { g) }\end{array}$ & $\begin{array}{l}\text { Total phenolic } \\
\text { content } \\
\text { (mg GA Eq./g) }\end{array}$ & $\begin{array}{l}\text { Total chlorophylls } \\
\text { content } \\
(\mathrm{mg} / \mathrm{g})\end{array}$ & $\begin{array}{l}\text { Total carotenoids } \\
\text { content } \\
(\mathrm{mg} / \mathrm{g})\end{array}$ \\
\hline \multirow{4}{*}{ Ohmic heating } & & Extraction $1 \mathrm{~h}$ & & & & \\
\hline & 100:0 & $109 \pm 10.6^{\mathrm{cAB}}$ & $29.1 \pm 2.60^{\mathrm{aA}}$ & $1.26 \pm 0.02^{\mathrm{aA}}$ & $0.03 \pm 0.02^{\mathrm{aAB}}$ & $0.02 \pm 0.01^{\mathrm{aA}}$ \\
\hline & $75: 25$ & $94.3 \pm 9.30^{\mathrm{cAB}}$ & $75.6 \pm 5.30^{\mathrm{cC}}$ & $1.64 \pm 0.13^{\mathrm{bcAB}}$ & $0.06 \pm 0.02^{\mathrm{aA}}$ & $0.03 \pm 0.01^{\mathrm{aA}}$ \\
\hline & $50: 50$ & $43.0 \pm 3.90^{\mathrm{bAB}}$ & $60.9 \pm 3.50^{\mathrm{bB}}$ & $1.78 \pm 0.06^{\mathrm{cB}}$ & $0.18 \pm 0.01^{\mathrm{bB}}$ & $0.07 \pm 0.00^{\mathrm{bB}}$ \\
\hline \multirow{5}{*}{$\begin{array}{c}\text { Conventional } \\
\text { extraction }\end{array}$} & $25: 75$ & $12.8 \pm 0.30^{\mathrm{aB}}$ & $30.3 \pm 1.10^{\mathrm{aA}}$ & $1.51 \pm 0.01^{\mathrm{bA}}$ & $0.99 \pm 0.04^{\mathrm{cC}}$ & $0.18 \pm 0.00^{\mathrm{cB}}$ \\
\hline & $100: 0$ & $101 \pm 6.00^{\mathrm{dA}}$ & $27.6 \pm 2.00^{\mathrm{aA}}$ & $1.33 \pm 0.02^{\mathrm{aAB}}$ & $0.02 \pm 0.00^{\mathrm{aAB}}$ & $0.02 \pm 0.00^{\mathrm{aA}}$ \\
\hline & $75: 25$ & $76.6 \pm 4.30^{\mathrm{cA}}$ & $63.1 \pm 3.40^{\mathrm{dB}}$ & $1.53 \pm 0.08^{\mathrm{bA}}$ & $0.07 \pm 0.00^{\mathrm{bA}}$ & $0.04 \pm 0.00^{\mathrm{bAB}}$ \\
\hline & $50: 50$ & $31.9 \pm 0.50^{\mathrm{bA}}$ & $46.1 \pm 1.50^{\mathrm{cA}}$ & $1.50 \pm 0.02^{\mathrm{bA}}$ & $0.15 \pm 0.01^{\mathrm{cA}}$ & $0.06 \pm 0.00^{\mathrm{cA}}$ \\
\hline & $25: 75$ & $13.4 \pm 0.70^{\mathrm{aB}}$ & $38.1 \pm 3.60^{\mathrm{bB}}$ & $1.56 \pm 0.07^{\mathrm{bA}}$ & $0.60 \pm 0.01^{\mathrm{dA}}$ & $0.15 \pm 0.00^{\mathrm{dA}}$ \\
\hline \multirow{4}{*}{ Ohmic heating } & & Extraction $2 \mathrm{~h}$ & & & & \\
\hline & 100:0 & $140 \pm 1.10^{\mathrm{dC}}$ & $27.3 \pm 1.50^{\mathrm{aA}}$ & $1.39 \pm 0.02^{\mathrm{aBC}}$ & $0.01 \pm 0.00^{\mathrm{aA}}$ & $0.01 \pm 0.00^{\mathrm{aA}}$ \\
\hline & $75: 25$ & $106 \pm 8.20^{\mathrm{cB}}$ & $63.8 \pm 4.00^{\mathrm{cB}}$ & $1.80 \pm 0.06^{\mathrm{cB}}$ & $0.11 \pm 0.01^{\mathrm{bB}}$ & $0.09 \pm 0.00^{\mathrm{bC}}$ \\
\hline & $50: 50$ & $57.2 \pm 5.00^{\mathrm{bB}}$ & $51.7 \pm 2.00^{\mathrm{bA}}$ & $1.88 \pm 0.01^{\mathrm{cC}}$ & $0.25 \pm 0.00^{\mathrm{cC}}$ & $0.09 \pm 0.00^{\mathrm{bC}}$ \\
\hline \multirow{5}{*}{$\begin{array}{c}\text { Conventional } \\
\text { extraction }\end{array}$} & $25: 75$ & $13.2 \pm 0.40^{\mathrm{aB}}$ & $33.5 \pm 0.80^{\mathrm{aAB}}$ & $1.60 \pm 0.09^{\mathrm{bA}}$ & $0.75 \pm 0.03^{\mathrm{dB}}$ & $0.15 \pm 0.00^{\mathrm{cA}}$ \\
\hline & 100:0 & $124 \pm 4.00^{\mathrm{dBC}}$ & $29.5 \pm 1.80^{\mathrm{aA}}$ & $1.42 \pm 0.05^{\mathrm{aC}}$ & $0.04 \pm 0.01^{\mathrm{aB}}$ & $0.02 \pm 0.00^{\mathrm{aA}}$ \\
\hline & $75: 25$ & $78.0 \pm 5.90^{\mathrm{cA}}$ & $49.1 \pm 3.70^{\mathrm{bA}}$ & $1.58 \pm 0.04^{\mathrm{bAB}}$ & $0.09 \pm 0.01^{\mathrm{aAB}}$ & $0.04 \pm 0.00^{\mathrm{bB}}$ \\
\hline & $50: 50$ & $50.8 \pm 2.30^{\mathrm{bB}}$ & $47.5 \pm 2.20^{\mathrm{bcA}}$ & $1.82 \pm 0.03^{\mathrm{cBC}}$ & $0.25 \pm 0.02^{\mathrm{bC}}$ & $0.09 \pm 0.01^{\mathrm{cC}}$ \\
\hline & $25: 75$ & $10.9 \pm 0.20^{\mathrm{aA}}$ & $36.1 \pm 3.30^{\mathrm{aAB}}$ & $1.52 \pm 0.05^{\mathrm{abA}}$ & $0.76 \pm 0.06^{\mathrm{cB}}$ & $0.15 \pm 0.01^{\mathrm{dA}}$ \\
\hline
\end{tabular}

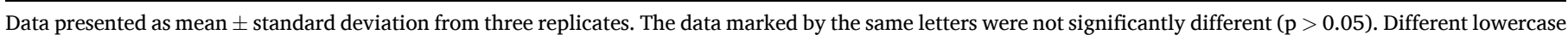

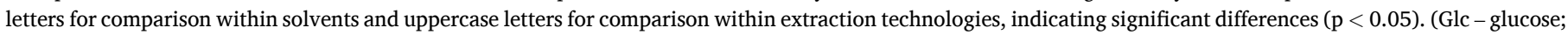
BSA - bovine serum albumin; GA - gallic acid).

extraction yield is generally low for the proteins and peptides [41]. It is also known that ethanol may precipitate some proteins [38] and that temperature may help opening the seaweed structure, thus facilitating extraction. In this study we observed a higher amount in extracted proteins with 75:25 and 50:50 water/ethanol solvents, since protein may be cohesive to carbohydrates, and these solvents also extracted a significant amount of carbohydrates. Furthermore, proteins that are insoluble in water may become soluble in different solvents, depending on the type of protein. For higher ethanol concentrations (25:75 water/ ethanol) less protein was extracted.

It is also known that heat treatment over time may denature protein or make them insoluble [42]. This fact could explain the results, as a decrease of protein content was observed at $2 \mathrm{~h}$ of extraction using all solvents on both methods when compared with $1 \mathrm{~h}$. Stronger or longer thermal treatments may induce enough denaturation to expose hydrophobic sites that would cause incompatibility with more polar solvents (such as water) leading to protein precipitation. In this case, protein that was initially solubilized would precipitate and deposit in the solid residue. Furthermore, much more protein was extracted at $1 \mathrm{~h}$ with $\mathrm{OH}$. This better extraction using $\mathrm{OH}$ can be a result of several events associated to the nature of technology, such as: i) enhanced extraction due to combination of thermal and electrical effects; ii) less thermal load and denaturation due to direct heating effect; iii) protein structural and conformational modifications, as described previously by Rodrigues 
et al. [27]; and iv) occurrence of protein hydrolysis.

Algae protein are generally considered a potential good source of protein $[41,43,44]$. However, they have poor digestibility in their unprocessed form due to a high content in fibres and eventually polyphenols [45], and protein extraction is needed to improve bioavailability [46]. There are also limitations in the protein extractability due to the type of protein (low solubility), the complex algae and cell architecture and strong interaction between protein and other different algae components [45,47]. In these context, the extracts obtained reached $48 \%$ content in protein which indicates interesting feasibility for their use, still without any purification procedure.

\subsubsection{Total phenolic compounds}

The total phenolic content (mg per $\mathrm{g}$ extract) of the extracts and extraction yield in phenolic compounds (mg per $\mathrm{g}$ seaweed) are shown in Tables 3 and 4, respectively.

Yields and contents were overall low and with small differences between solvents, as expected because this seaweed usually has a very low initial content of phenolic compounds. The 75:25 and 50:50 water/ ethanol solvents were the best solvents in terms of total phenolic extraction yield (increase between 15 and $30 \%$ for $\mathrm{OH}$ and $5-20 \%$ for $\mathrm{CE}$ ), in comparison with the other ratios. However, total phenolic content in the extracts was higher when the 50:50 and 25:75 water/ethanol solvents were used (15-50\% for $\mathrm{OH}$ and $20-50 \%$ for $\mathrm{CE}$ ). The extraction of phenolic compounds depends on the type of solvent used and its selectivity. Intermediate hydroethanolic solvents showed higher yield in the extraction of phenolic compounds than just water as solvent, as expected. Polar organic solvents extract better polyphenolic compounds compared to water [38]. Theoretically, ethanol:water $(80: 20, \mathrm{v} / \mathrm{v})$ is the best ratio to extract phenolic compounds [38].

According to Liu et al. [48], it is known that carbohydrates, proteins and phenolic compounds can reversibly and irreversibly interact, forming a binary or tertiary conjugates due to covalent interactions with nutritional and functional properties [48]. The slight increase of phenolic compounds in 75:25 and 50:50 water/ethanol ratios, when compared to 25:75 water/ethanol, may be due to the dragging of these compounds by the higher extraction of sugars and proteins, and not due to the extraction of phenolic compounds "itself".

As for the differences between treatments, they were only significant when 50:50 water/ethanol was used as solvent during $1 \mathrm{~h}$ of extraction. In this case, $\mathrm{OH}$ displayed an increase of approximately $16 \%$ when compared to CE $(p<0.05)$. After $2 \mathrm{~h}$, this effect was diluted once at the final extractable phenolics were the same, by both methods. However, $\mathrm{OH}$ allowed an initial increase in the kinetics of extraction eventually due to an electroporation effect or efficient heating. This means that $\mathrm{OH}$ bring the advantage of shortening time needed for extraction. Previous studies with electric-fields-based technologies have already reported an increase in the extraction of phenolic compounds and essential oils from different matrices compared to traditional methods [26,49-51].

\subsubsection{Photosynthetic pigments}

The results for photosynthetic pigments ( $\mathrm{mg}$ per g extract and mg per $g$ seaweed), measured as the equivalent amount of total chlorophylls and carotenoids, extracted by the different methods using different solvents are presented in Tables 3 and 4, respectively.

Globally, the increase of ethanol concentration provided a significant increase of pigments extraction using both methods. Residual extraction of pigments was observed using $100 \%$ water. Generally, on both extraction methods, $1 \mathrm{~h}$ of extraction showed higher amounts in pigments than $2 \mathrm{~h}$, probably indicating some thermal degradation over time. However, $\mathrm{OH}$ using 25:75 water/ethanol at $1 \mathrm{~h}$ of extraction proved to be the best condition for pigments extraction when compared with the other conditions, by exhibiting in mg per $\mathrm{g}$ of extract an increase of total chlorophylls and carotenoids of approximately $50 \%$ and $40 \%$, respectively, and in mg per g seaweed an increase of 40 and $20 \%$, respectively.
According to literature, red seaweeds contain chlorophyll $a$, phycobilins (R-phycocyanin and R-phycoerythrin) and carotenoids ( $\beta$-carotene, lutein and zeaxanthin) as main pigments [3]. Phycobilins were not determined in this work, however it has been described that they are protein-pigment complexes and are usually included in the protein quantification [3]. In the present study, the chlorophylls were found in higher amount, but these seaweeds also contain carotenoids.

\subsubsection{Antioxidant activity}

The antioxidant activity of the extracts (measured by the FRAP and ABTS methods) is shown in Fig. 1 and increased with the percentage of ethanol. Overall, in both extraction methods, differences in the extraction time were generally not significant, except for $1 \mathrm{~h}$ using 25:75 water/ethanol solvent (FRAP and ABTS) and using 50:50 water/ethanol solvent (ABTS). The antioxidant activity of 50:50 and 25:75 water/ ethanol was 3-fold and 5-fold higher than $100 \%$ water, respectively.

Furthermore, the increase of antioxidant activity was in line with the pigment content and in minor extent with phenolic content. Though the extraction yield in these compounds was low, antioxidant activity of the extracts was significant.

The antioxidant compounds have reducing properties and can donate electrons and reduce the oxidized intermediates compounds. The results obtained in this study showed a good antioxidant activity and that this bioactivity had a positive correlation with pigments content. The condition with higher antioxidant activity was corroborated with a higher pigment content (25:75 water/ethanol solvent at $1 \mathrm{~h}$ ), confirming the correlation. Carotenoids have been described as antioxidants, that have the ability of inactive reactive oxygen species formed by light and air exposure, anticancer and anti-aging agents [52], and chlorophylls have anticancer activity [53]. However, other seaweeds' components have shown antioxidant potential, including sulphated polysaccharides [54], phycobiliproteins and lectins [10], and phenolic compounds [38].

\subsection{Agar-enriched fraction characterization}

\subsubsection{Extraction yield}

Fig. 2 shows the effects of two extraction methods on the agarenriched fraction yields (based on the fraction separated by the freezethawing method) using different ratios of water and ethanol at $1 \mathrm{~h}$ and $2 \mathrm{~h}$ of extraction. The final water content of agar-enriched fractions was below $11 \%$.

The extraction yields of the agar-enriched fraction ranged from 2 to $29 \%$. Higher yields were found in 75:25 water/ethanol (23-29\%), followed by $100 \%$ water (16-19\%), 50:50 water/ethanol (7-16\%) and 25:75 water/ethanol (2-4\%). In both methods used, OH and CE, $2 \mathrm{~h}$ of extraction displayed a significant higher agar-enriched fraction yield than $1 \mathrm{~h}$, except the $\mathrm{CE}$ with 25:75 water/ethanol solvent. Globally, $\mathrm{OH}$ seems to be more efficient in the agar-enriched fraction extraction, particularly for $100 \%$ water after $2 \mathrm{~h}$, and 75:50 and 50:50 water/ ethanol after $1 \mathrm{~h}$.

It is known that agar yield depends on the seaweed's species, development stages and environmental conditions [55] and could range from 6 to 71\% [18]. More specifically, Gracilaria native agar yields are typically around $10-15 \%$ (ranging hugely) but can increase when using alkali pretreatment (15-33\%) [18]. The agar fractions obtained in this work by the freeze-thawing method are within these expected ranges.

\subsubsection{Carbohydrate content and monosaccharide profile}

The carbohydrate content per $g$ of agar-enriched fraction is presented in Fig. 3. Both extraction methods displayed higher values in $100 \%$ water $(570-680 \mathrm{mg} / \mathrm{g}$ ) and decreased in the following order: $75: 25$ water/ethanol $(280-380 \mathrm{mg} / \mathrm{g})>50: 50$ water/ethanol (300-340 $\mathrm{mg} / \mathrm{g})>25: 75$ water/ethanol $(130-210 \mathrm{mg} / \mathrm{g})$. The carbohydrate content using $100 \%$ water for extraction was approximately 2 -fold higher than 75:25 and 50:50 water/ethanol and 3-fold higher when compared to 25:75 water/ethanol. At $2 \mathrm{~h}$ of extraction, $\mathrm{OH}$ and $\mathrm{CE}$ using 

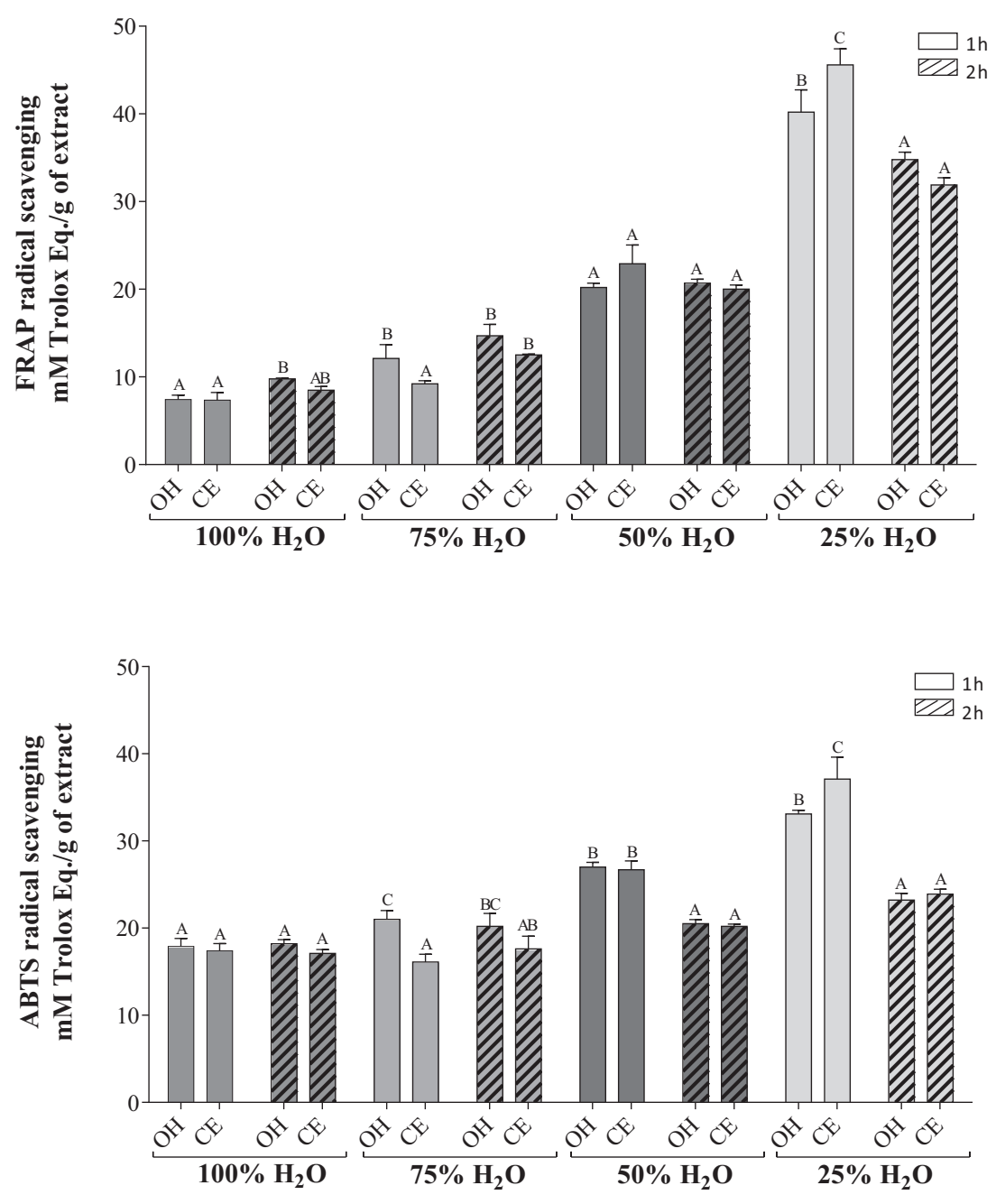

Fig. 1. Effect of ohmic heating $(\mathrm{OH})$ and conventional extraction (CE) on ferric reducing antioxidant power (FRAP) and 2,2-azino-bis(3-ethylbenzothiazoline)-6 sulphonic acid (ABTS) radical scavenging assay of different solvent ratio at 1 $\mathrm{h}$ and $2 \mathrm{~h}$ of extraction expressed in $\mathrm{mM}$ Trolox equivalent per $\mathrm{g}$ of extract. Data presented as mean \pm standard deviation from three replicates. The data marked by the same letters were not significantly different $(p>0.05)$. Different uppercase letters for comparison within extraction technologies when used the same solvent ratios, indicating significant differences $(p<0.05)$.

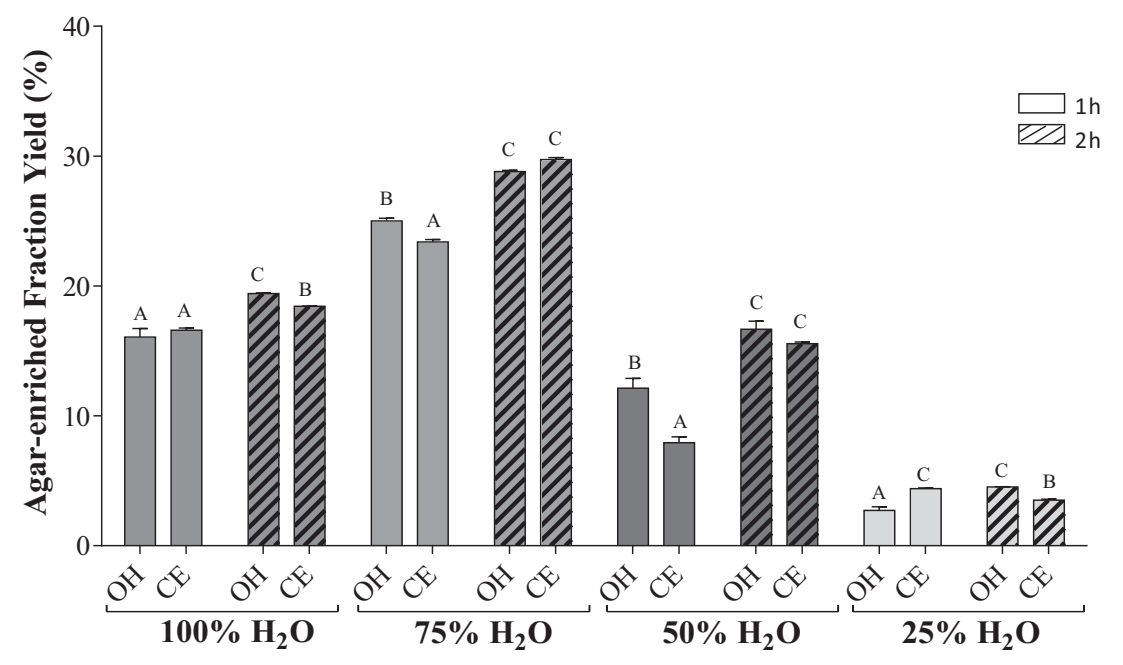

Fig. 2. Effect of ohmic heating $(\mathrm{OH})$ and conventional extraction (CE) on the yield of agar-enriched fraction of different solvent ratio at $1 \mathrm{~h}$ and $2 \mathrm{~h}$ of extraction, expressed in percentage (\%). Data presented as mean \pm standard deviation from three replicates. The data marked by the same letters were not significantly different ( $p>0.05$ ). Different uppercase letters for comparison within extraction technologies when used the same solvent ratios, indicating significant differences ( $<0.05$ ).

100\% water had higher carbohydrate content than $1 \mathrm{~h}$. For 75:25 water/ ethanol solvent this increase was only observed using $\mathrm{OH}$.

As said above in Section 3.2.2, extraction using $100 \%$ water as a solvent can extract polar compounds such as carbohydrates with much more efficiency [38], as seen in Fig. 3. At $2 \mathrm{~h}$ of extraction the highest value of carbohydrates extracted was observed, as expected, since the 


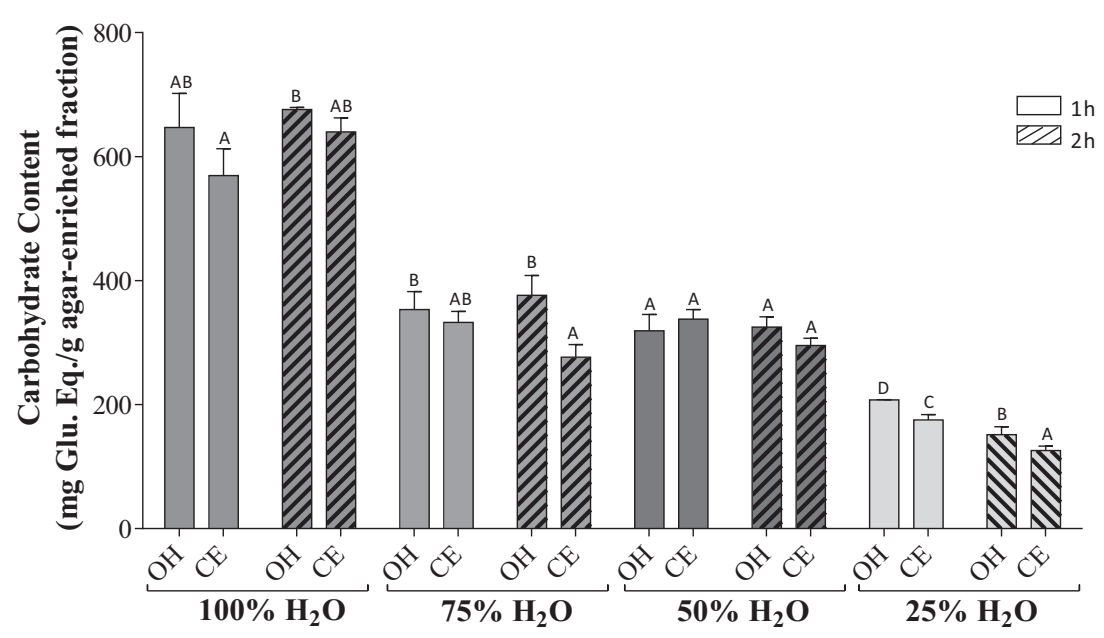

Fig. 3. Effect of ohmic heating $(\mathrm{OH})$ and conventional extraction (CE) on the carbohydrate content of different solvent ratio at $1 \mathrm{~h}$ and $2 \mathrm{~h}$ of extraction, expressed in mg glucose equivalent per $\mathrm{g}$ of agar-enriched fraction. Data presented as mean \pm standard deviation from three replicates. The data marked by the same letters were not significantly different ( $p$ $>$ 0.05). Different uppercase letters for comparison within extraction technologies when used the same solvent ratios, indicating significant differences $(p<0.05)$. agar is the main carbohydrate present in Gracilaria sp. and several studies reported that $2 \mathrm{~h}$ is the optimum time of extraction $[8,19,56]$. In fact, as agar is mainly soluble in hot water, the melting point is generally high $\left(>80^{\circ} \mathrm{C}\right)$, and time is needed to allow solubilization and migration towards the solvent. Though the agar-enriched fraction (main carbohydrate) can be recovered by the freeze-thawing method, some carbohydrates remain soluble in the syneresis water after the freeze-thawing process.

The sugars composition of agar-enriched fraction is shown in Table 5. The sugars composition of $\mathrm{OH}$ and $\mathrm{CE}$ for all ratio of water/ ethanol for $1 \mathrm{~h}$ and $2 \mathrm{~h}$ of extraction is identical, being mainly composed by galactose ( 25 to $206 \mathrm{mg} / \mathrm{g}$ ) and 3,6-anhydrogalactose (14 to $160 \mathrm{mg}$ / $\mathrm{g}$ ), confirming that the main soluble polysaccharide is agar. Glucose, mannose, uronic acids, and naturally methylated sugars, 6-O-metilgalactose and 4-O-metil-galactose, were also determined at lower amounts (less than $85 \mathrm{mg} / \mathrm{g}$ ). The relative amount of galactose and 3,6anhydrogalactose slightly decreased in $\mathrm{OH}$ comparing with the $\mathrm{CE}$ with the concomitant increase of uronic acids. The presence of uronic acids may infer the presence of agaropectin. In addition, it was further observed an overall increase of total sugars in $\mathrm{OH}$ than $\mathrm{CE}$, particularly for $2 \mathrm{~h}$ of extraction, which corroborates with the values obtained above in the PSA method.

\subsubsection{Agar structure}

FTIR spectra of agar-enriched fraction obtained from $\mathrm{OH}$ and $\mathrm{CE}$ with $100 \%$ water for $2 \mathrm{~h}$, are presented in Fig. 4 . All agar-enriched fractions exhibited similar peaks. The absorption at 1250 and $1370 \mathrm{~cm}^{-1}$, related to total sulfate $(\mathrm{S}=\mathrm{O}$ stretching vibration and ester sulfates, respectively) [57], was identified in all agar-enriched fractions. However, they are small shoulders which could indicate lower amounts of sulfate, and the peaks of agar-enriched fraction from $\mathrm{OH}$ are smaller than from conventional extraction, which could indicate that they have a lower amount of sulfate.

\subsubsection{Gel strength}

Gel strengths of the agar-enriched fractions were evaluated under extraction conditions of 100\% water, 75:25 water/ethanol and 50:50 water/ethanol and are shown in Fig. 5. Not enough solid content was recovered from the 25:75 water/ethanol assays, thus, gel strength was not performed for this condition.

On both extraction methods, agar-enriched fraction extracted with $100 \%$ water presented a higher gel strength $\left(227-313 \mathrm{~g} / \mathrm{cm}^{2}\right)(p<0.05)$ than $50: 50$ water/ethanol $\left(61-73 \mathrm{~g} / \mathrm{cm}^{2}\right)$ and $75: 25$ water/ethanol $\left(37-43 \mathrm{~g} / \mathrm{cm}^{2}\right)$. There were no significant differences between the times of extraction. OH using $100 \%$ water allowed for the obtention of an extract with significant higher gel strength compared to CE (ca. 20 and

Table 5

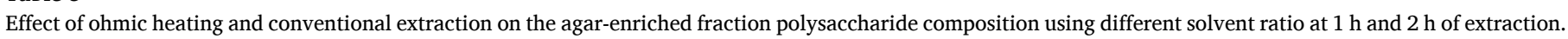
Results are expressed in mg per $g$ of agar-enriched fraction.

\begin{tabular}{|c|c|c|c|c|c|c|c|c|c|c|c|c|c|}
\hline & $\mathrm{H}_{2} \mathrm{O}: \mathrm{EtOH}$ & Rha & Fuc & Rib & 3,6-AnGal & Xyl & 6-O-Me-Gal & 4-O-Me-Gal & Man & Gal & Glc & UA & Total \\
\hline & & \multicolumn{12}{|c|}{ Extraction $1 \mathrm{~h}$} \\
\hline \multirow[t]{4}{*}{ Ohmic heating } & 100:0 & 0 & 0 & 1 & 124 & 2 & 45 & 2 & 23 & 196 & 7 & 85 & 485 \\
\hline & $75: 25$ & 0 & 0 & 1 & 53 & 1 & 24 & 5 & 11 & 111 & 10 & 56 & 272 \\
\hline & $50: 50$ & 1 & 0 & 1 & 66 & 2 & 33 & 4 & 16 & 108 & 8 & 55 & 294 \\
\hline & $25: 75$ & 1 & 1 & 0 & 14 & 1 & 9 & 2 & 3 & 25 & 9 & 32 & 97 \\
\hline \multirow[t]{5}{*}{ Conventional extraction } & 100:0 & 0 & 0 & 1 & 137 & 2 & 44 & 2 & 26 & 206 & 9 & 23 & 450 \\
\hline & $75: 25$ & 0 & 0 & 1 & 51 & 1 & 23 & 5 & 11 & 109 & 11 & 15 & 227 \\
\hline & $50: 50$ & 0 & 0 & 0 & 60 & 1 & 29 & 2 & 14 & 94 & 7 & 15 & 222 \\
\hline & $25: 75$ & 1 & 1 & 1 & 44 & 1 & 25 & 2 & 11 & 62 & 7 & 13 & 168 \\
\hline & & \multicolumn{12}{|c|}{ Extraction $2 \mathrm{~h}$} \\
\hline \multirow[t]{4}{*}{ Ohmic heating } & 100:0 & 0 & 0 & 2 & 160 & 3 & 60 & 6 & 65 & 191 & 6 & 43 & 536 \\
\hline & $75: 25$ & 0 & 0 & 2 & 53 & 1 & 21 & 5 & 12 & 92 & 12 & 33 & 231 \\
\hline & $50: 50$ & 0 & 1 & 1 & 103 & 1 & 48 & 3 & 27 & 147 & 9 & 34 & 374 \\
\hline & $25: 75$ & 1 & 1 & 1 & 27 & 1 & 17 & 1 & 4 & 29 & 10 & 28 & 120 \\
\hline \multirow[t]{4}{*}{ Conventional extraction } & $100: 0$ & 0 & 1 & 2 & 148 & 2 & 38 & 1 & 26 & 160 & 11 & 21 & 410 \\
\hline & $75: 25$ & 0 & 1 & 2 & 81 & 2 & 28 & 4 & 14 & 108 & 15 & 8 & 263 \\
\hline & $50: 50$ & 0 & 1 & 2 & 92 & 1 & 36 & 3 & 21 & 106 & 8 & 11 & 281 \\
\hline & $25: 75$ & 1 & 1 & 2 & 30 & 1 & 20 & 2 & 4 & 32 & 15 & 9 & 117 \\
\hline
\end{tabular}

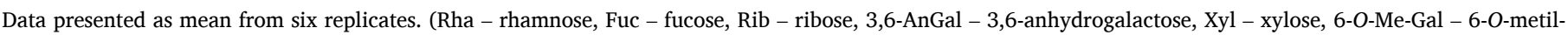
galactose, 4-O-Me-Gal - 4-O-metil-galactose, Man - mannose, Gal - galactose, Glc - glucose, UA - uronic acids). 


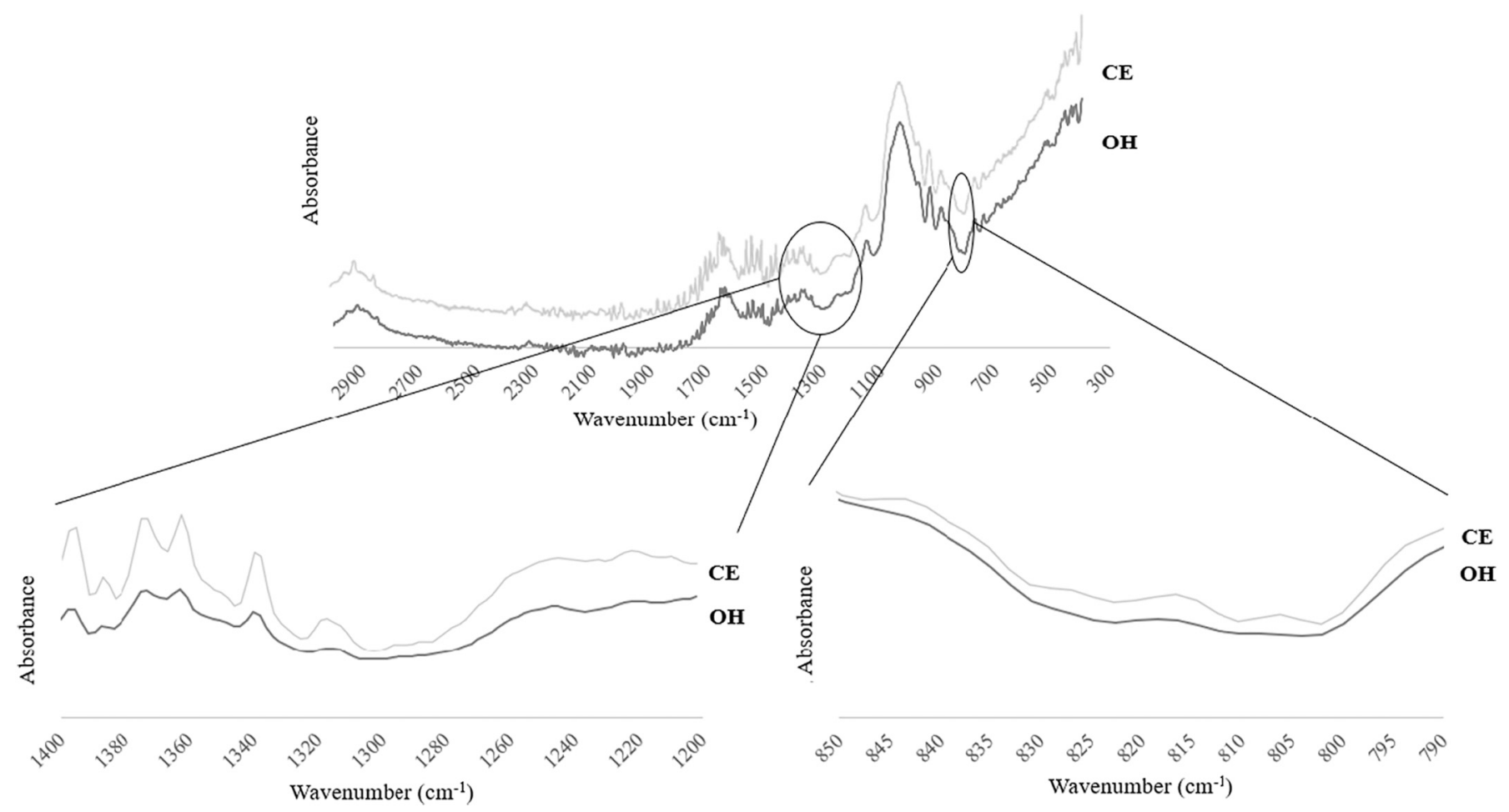

Fig. 4. Fourier Transform Infrared Spectroscopy (FTIR) spectra of ohmic heating (OH) and conventional extraction (CE) on the agar-enriched fraction of $100 \%$ water at $2 \mathrm{~h}$ of extraction.

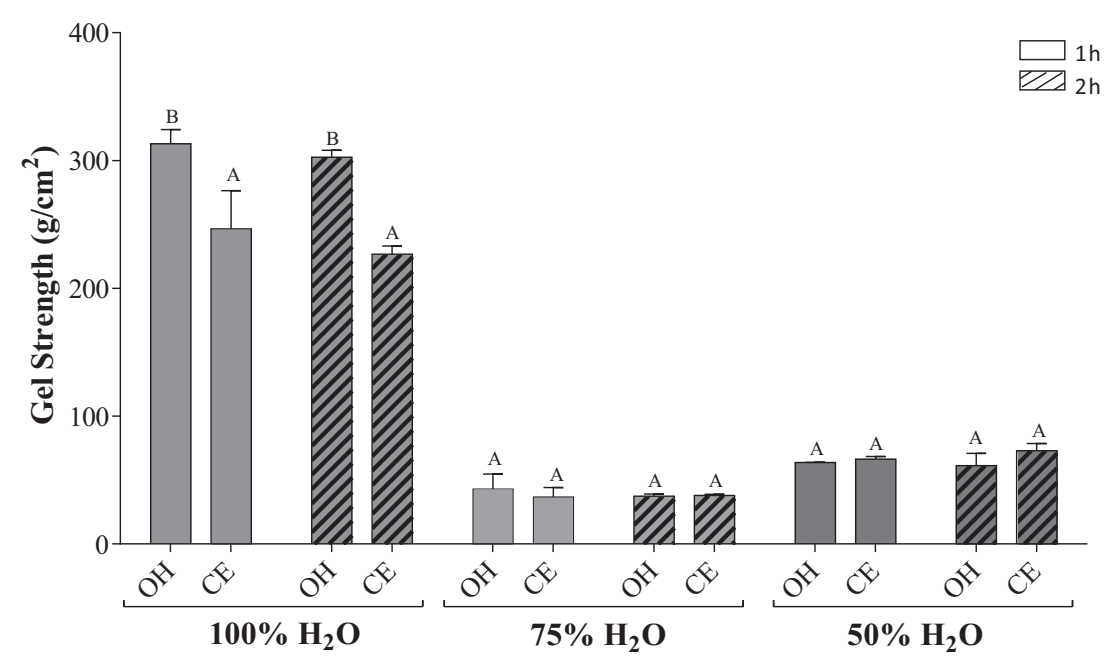

Fig. 5. Effect of ohmic heating $(\mathrm{OH})$ and conventional extraction (CE) on the gel strength of different solvent ratio at $1 \mathrm{~h}$ and $2 \mathrm{~h}$ of extraction, expressed in $\mathrm{g}$ per $\mathrm{cm}^{2}$. Data presented as mean \pm standard deviation from three replicates. The data marked by the same letters were not significantly different $(p>0.05)$. Different uppercase letters for comparison within extraction technologies when used the same solvent ratios, indicating significant differences $(p<0.05)$.

$25 \%$ at $1 \mathrm{~h}$ and $2 \mathrm{~h}$, respectively) $(p<0.05)$. These results corroborate the carbohydrate content expressed per $g$ of agar-enriched fraction. The gel strength of agar-enriched fraction using 50:50 water/ethanol showed a higher gel strength compared to 75:25 water/ethanol solvent, which is in agreement with the higher 3,6-anhydrogalactose content in $50: 50$ ( $60-66 \mathrm{mg} / \mathrm{g}$ for $1 \mathrm{~h}$ and $92-103 \mathrm{mg} / \mathrm{g}$ for $2 \mathrm{~h}$ of extraction) than 75:25 (51-53 mg/g for $1 \mathrm{~h}$ and 53-81 mg/g for $2 \mathrm{~h}$ ) water/ethanol.

Hydrocolloids such as agar are able to form a viscous solution when dissolved in water [53]. This ability is explored for many different applications, such as texturization, gelling, water retention, and others. Thus, gel strength of the fraction rich in agar (as the other fractions did not form a gel) was assessed as a measure of the impact of the electric fields in the technological functionality of the extracts. In the gel strength, a very promising result was obtained by the $\mathrm{OH}$ technology using $100 \%$ water when compared to CE $(p<0.05)$. Also, on both extraction methods, the gel strengths obtained in this study from native agars using $100 \%$ water were higher than those reported by Villanueva et al. [19] (55-115 $\left.\mathrm{g} / \mathrm{cm}^{2}\right)$.

Several factors can affect the extraction of agar, including alkali pretreatment, extraction temperature and duration. For Gracilaria species, the conditions described to produce agar with higher gel strengths include alkali concentrations between 3 and $10 \%(\mathrm{w} / \mathrm{v})$, extraction times ranging from 0.5 to $3 \mathrm{~h}$ at high temperatures of 80 to $90{ }^{\circ} \mathrm{C}$. It is known that gel strength is highly dependent on 3,6-anhydrogalactose 
and sulphate contents [18]. Further, an alkaline pre-treatment is commercially applied to remove sulfate groups and enhance agar gelling ability, in particular for algae species tipically with highly sulfated agar such as Gracilaria sp.

In this context, and as a proof-of-concept, an alkaline pre-treatment followed by extraction at the best conditions for agar recovery $(100 \%$ water, $2 \mathrm{~h}$ ) was performed. Results are presented in Table 6. Ohmic heating allowed also higher extraction yields in these conditions, with an improvement in the gel strength of more than $20 \%$.

Further, to extend the proof-of-concept, the pre-treated agar was purified through a simple solubilization/centrifugation/drying protocol to remove insoluble material, as the industrial setting is usually more efficient recovering agar with a higher degree of purity (e.g. pressing and filtering together with washing and dialysis are more efficient that the laboratory process in this respect). $\mathrm{OH}$ and $\mathrm{CE}$ showed a purification percentage of agar-enriched fraction of $>80 \%$ and $>70 \%$, respectively. Gel strengths increased and matched (for the CE) or surpassed by $23 \%$ (for $\mathrm{OH}$ ) the commercial agar used for benchmarking (Table 6), indicating good feasibility prospects. Further, as a similar behavior is to be expected for the native agar if purified. This indicates that $\mathrm{OH}$ may be used to achieve commercially interesting agars without the need of the alkali pre-treatment, reducing the need for chemicals, resulting in a greener and more sustainable process. Therefore, without the alkaline pre-treatment, the different seaweed extracts may have potential commercial interest (e.g. proteins can also be used as textural enhancers, emulsifiers, among others). This would not occur with the commercial agar, because the harsh alkali treatment would not allow it.

\subsection{Overall discussion}

In general, differences in the extraction of each family of compounds between ohmic heating and conventional extraction treatments were more pronounced at the expected optimum conditions of each compound: 1) 10-30\% increase in the extraction of carbohydrates after $2 \mathrm{~h}$ for the solvents with more water (100\% and 75:25 water/ethanol), respectively; 2) $20 \%$ increase in the protein extracted with $75 \%$ water (for both times) and 30\% increase in the protein extracted with $50 \%$ water for $1 \mathrm{~h}$; 3) $40 \%$ increase in the chlorophylls content and $20 \%$ increase in the carotenoids content when 25:75 water/ethanol was used for $1 \mathrm{~h}$; and 4) up to $15 \%$ increase in the extraction of phenolic compounds for intermediate water/ethanol mixtures (50:50 water/ethanol) at $1 \mathrm{~h}$ of extraction. In the case of pigments, this increased content at $1 \mathrm{~h}$ of extraction for $\mathrm{OH}$ is not reflected in the final value at $2 \mathrm{~h}$, which is

\section{Table 6}

Effect of ohmic heating and conventional extraction with water as solvent at $2 \mathrm{~h}$ of extraction on the total yield, agar yield and gel strength with an alkaline pretreatment and purification, conductivity was adjusted to $1 \mathrm{mS} / \mathrm{cm}$ in both cases; and the native agar-enriched fraction yield and gel strength and commercial agar gel strength.

\begin{tabular}{|c|c|c|c|}
\hline Type of agar & Parameter & $\begin{array}{l}\text { Ohmic } \\
\text { heating }\end{array}$ & $\begin{array}{l}\text { Conventional } \\
\text { extraction }\end{array}$ \\
\hline \multirow[t]{2}{*}{ Native } & Agar yield (\%) & $\begin{array}{l}19.42 \pm \\
0.06\end{array}$ & $18.44 \pm 0.01$ \\
\hline & $\begin{array}{l}\text { Gel strength }(\mathrm{g} / \\
\left.\mathrm{cm}^{2}\right)\end{array}$ & $313 \pm 1.72$ & $247 \pm 5.86$ \\
\hline \multirow[t]{3}{*}{ Pre-treated } & Total yield (\%) & $17.4 \pm 0.30$ & $14.8 \pm 0.30$ \\
\hline & Agar yield (\%) & $12.6 \pm 0.60$ & $10.8 \pm 0.90$ \\
\hline & $\begin{array}{l}\text { Gel strength }(\mathrm{g} / \\
\left.\mathrm{cm}^{2}\right)\end{array}$ & $426 \pm 24.0$ & $348 \pm 12.0$ \\
\hline \multirow[t]{2}{*}{$\begin{array}{l}\text { Pre-treated and } \\
\text { purified }\end{array}$} & $\begin{array}{l}\text { Purification yield } \\
(\%)\end{array}$ & $\begin{array}{l}81.47 \pm \\
0.26\end{array}$ & $74.21 \pm 1.52$ \\
\hline & $\begin{array}{l}\text { Gel strength }(\mathrm{g} / \\
\left.\mathrm{cm}^{2}\right)\end{array}$ & $632 \pm 24.0$ & $544 \pm 15.0$ \\
\hline Commercial & $\begin{array}{l}\text { Gel strength }(\mathrm{g} / \\
\left.\mathrm{cm}^{2}\right)\end{array}$ & $612 \pm 0.32$ & \\
\hline
\end{tabular}

Data presented as mean \pm standard deviation. lower and equal for both technologies. This may indicate that besides an increased extraction kinetics with $\mathrm{OH}$ that allows extracting in a shorter time, some pigments may degrade with time and temperature and both phenomena should be considered when designing an extraction methodology for these compounds. Further, a sequential extraction may be proposed, where ethanolic treatments (for instance, 50:50 water/ ethanol) may be tuned to extract maximum proteins or other target biocompounds, followed by the tuning of the aqueous treatment to extract agar, resulting in the valorization of at least two different fractions of seaweed, while removing possible contaminants from the aqueous extraction step (agar).

Gracilaria sp. are known to be agarophytes and their main commercial application is in the hydrocolloids industry for the production of agar. Therefore, an agar-enriched fraction was recovered from the extract by freeze-thawing and a deeper characterization of this fraction in terms of total carbohydrates, gelling ability and monosaccharides profile was made. $100 \%$ water solvent showed the highest carbohydrate content and gel strength due to the higher solubility of sugars in water and these values were higher for the OH-based process. Though the overall yield was also higher with $100 \%$ water solvent, which was expected because carbohydrates (and in particular agar) are the main components of Gracilaria, the yield in the agar-enriched fraction was higher when 75:25 water/ethanol was used. Though agar is expected to be extracted easier with $100 \%$ water solvent, $75: 25$ water/ethanol ratio may allow simultaneously extraction of carbohydrates and less polar compounds (including proteins) soluble in hydroethanolic solvents. This correlates well with the fact that protein extraction was higher in solvents with an intermediate content in ethanol (25 and 50\%). The carbohydrate profiles for both technologies were very similar, though $\mathrm{OH}$ recovered agar fraction seems to have a slightly higher uronic acids content.

The CE of agar from seaweeds (aqueous extraction) is generally performed using a water bath at high (even boiling) temperatures since it strongly affects the characteristics of the extracted polymer [58]. Furthermore cold extraction processes show low agar yields [9]. This means that, besides influencing composition and selectivity, $\mathrm{OH}$ can present a strong energetic advantage over traditional processes. For instance, Pereira et al. [26] have proven this advantage in extraction of anthocyanins from colored potato (treatments at $90{ }^{\circ} \mathrm{C}$ ) and FerreiraSantos et al. [51] have proven this advantage in extraction of phenolic compounds from Pinus pinaster bark, in treatments at $83{ }^{\circ} \mathrm{C}$, both at laboratory scale.

In terms of functionality, the gelling ability of extracted polysaccharides (agar) was not impaired by the use of moderate electric fields and there was an effective increase when water was used as solvent, probably related with the higher proportion of carbohydrates in the extracts obtained with this solvent combined with a possible partial removal of agar's sulfate groups. Furthermore, the antioxidant activity was also not impaired by the electric fields, and the profile was similar to pigments extraction's profiles, with $\mathrm{a} \approx 10 \%$ increase for the extraction with $\mathrm{OH}$ for $1 \mathrm{~h}$ with 25:75 water/ethanol.

These results indicate that the combined action of the solvent's selectivity towards a certain compound and $\mathrm{OH}$ (possibly due to an electroporation effect of the electric field or a local thermal effect caused by the $\mathrm{OH}$ in the seaweed structure) is facilitating the extraction mainly of the compounds with higher affinity towards the solvent, resulting in a very positive effect on the extraction efficiency and selectivity towards the desired compound. Furthermore, eventual protective effect of the moderate electric fields applied on the denaturation of the proteins should also be considered.

\section{Conclusions}

The results of the present work showed that different seaweed extracts can be achieved with different extraction times, types of solvent and extraction technologies. Ohmic heating allowed to enhance the 
selective action of the solvent, leading to higher extraction yields for the compound of interest when the appropriate solvent (with high affinity towards the target) was used. Furthermore, there seems to be a kinetic effect of $\mathrm{OH}$, which accelerates the extraction of some types of compounds, allowing the maximum extraction to be achieved at shorter times when compared to the traditional process. These selective features can be used to tune a sequential extraction process in order to use all fractions of seaweed, towards a zero-waste scenario. Thus, OH can be an interesting alternative to conventional extraction by being more efficient, faster and with reduced energy consumption. This may result in lower operational costs and in an environmental-friendly system to extract different compounds of interest, allowing to recover functional ingredients or additives from seaweeds for the food industry.

However, further knowledge on the thermal degradation and hydrolysis kinetics of the different compounds, as well as on the electroporation mechanism is relevant to allow mastering the mechanisms involved and take full advantage of the $\mathrm{OH}$ technology for extraction purposes. Furthermore, more research is needed in order to fully understand the interactions between compounds, solvents and matrix and the role of the electric fields on those interactions.

\section{CRediT authorship contribution statement}

Sara G. Pereira: Methodology, Investigation, Data curation, Formal analysis, Visualization, Writing - original draft. Catarina TeixeiraGuedes: Methodology, Investigation, Data curation, Formal analysis, Visualization, Writing - original draft. Gabriela Souza-Matos: Methodology, Investigation, Formal analysis, Writing - original draft. Élia Maricato: Methodology, Investigation, Formal analysis, Writing - review \& editing. Cláudia Nunes: Conceptualization, Methodology, Writing - review \& editing, Supervision, Funding acquisition. Manuel A. Coimbra: Conceptualization, Writing - review \& editing, Funding acquisition, Supervision, Resources. José A. Teixeira: Conceptualization, Writing - review \& editing, Funding acquisition, Resources, Supervision. Ricardo N. Pereira: Conceptualization, Methodology, Writing - review \& editing, Supervision. Cristina M.R. Rocha: Conceptualization, Methodology, Investigation, Resources, Formal analysis, Writing - review \& editing, Supervision, Funding acquisition.

\section{Declaration of competing interest}

The authors declare that they have no known competing financial interests or personal relationships that could have appeared to influence the work reported in this paper.

\section{Acknowledgments}

This work was supported by the Portuguese Foundation for Science and Technology (FCT) under the scope of project OH2O - PTDC/EQUEQU/029145/2017 and the strategic funding of UID/BIO/04469/2019 unit, and by the European Fund for Regional Development (FEDER) and COMPETE 2020 - Competitiveness and Internationalization Operational Program under the scope the projects OH2O (POCI-01-0145-FEDER029145) and VALORMAR - Full valorization of marine resources: potential, technological innovation and new applications (call 10/SI/2016; reference: 24517). This work was also developed within the scope of the stratigic funding of CICECO-Aveiro Institute of Materials (UIDB/50011/ 2020 \& UIDP/50011/2020), QOPNA (UID/QUI/00062/2019) and LAQV-REQUIMTE (UIDB/50006/2020), financed by national funds through the FCT/MEC and when appropriate co-financed by FEDER under the PT2020 Partnership Agreement. This work was also funded by national funds (OE), through FCT, I.P., within the scope of the framework contract foreseen in the numbers 4,5 and 6 of the article 23, of the Decree-Law $57 / 2016$, of August 29, changed by Law $57 / 2017$, of July 19.

\section{Statement of informed consent, human/animal rights}

No conflicts, informed consent, or human or animal rights are applicable to this study.

\section{References}

[1] M. Francavilla, M. Franchi, M. Monteleone, C. Caroppo, The red seaweed gracilaria gracilis as a multi products source, Mar. Drugs 11 (2013) 3754-3776, https://doi. org $/ 10.3390 / \mathrm{md} 11103754$.

[2] S. Lordan, R.P. Ross, C. Stanton, Marine bioactives as functional food ingredients: potential to reduce the incidence of chronic diseases, Mar. Drugs 9 (2011) 1056-1100, https://doi.org/10.3390/md9061056.

[3] S. Cardoso, L. Carvalho, P. Silva, M. Rodrigues, O. Pereira, L. Pereira, Bioproducts from seaweeds: a review with special focus on the Iberian Peninsula, Curr. Org. Chem. 18 (2014) 896-917, https://doi.org/10.2174/ 138527281807140515154116.

[4] A. Robin, P. Chavel, A. Chemodanov, A. Israel, A. Golberg, Diversity of monosaccharides in marine macroalgae from the Eastern Mediterranean Sea, Algal Res. 28 (2017) 118-127, https://doi.org/10.1016/j.algal.2017.10.005.

[5] P.R. Postma, O. Cerezo-Chinarro, R.J. Akkerman, G. Olivieri, R.H. Wijffels, W. A. Brandenburg, M.H.M. Eppink, Biorefinery of the macroalgae Ulva lactuca: extraction of proteins and carbohydrates by mild disintegration, J. Appl. Phycol. 30 (2018) 1281-1293, https://doi.org/10.1007/s10811-017-1319-8.

[6] G. Surget, K. Le Lann, G. Delebecq, N. Kervarec, A. Donval, M.A. Poullaouec, I. Bihannic, N. Poupart, V. Stiger-Pouvreau, Seasonal phenology and metabolomics of the introduced red macroalga Gracilaria vermiculophylla, monitored in the Bay of Brest (France), J. Appl. Phycol. 29 (2017) 2651-2666, https://doi.org/10.1007/ s10811-017-1060-3.

[7] M.H. Abreu, R. Pereira, C. Yarish, A.H. Buschmann, I. Sousa-Pinto, IMTA with Gracilaria vermiculophylla: productivity and nutrient removal performance of the seaweed in a land-based pilot scale system, Aquaculture. 312 (2011) 77-87, https://doi.org/10.1016/j.aquaculture.2010.12.036.

[8] A.M.M. Sousa, V.D. Alves, S. Morais, C. Delerue-Matos, M.P. Gonçalves, Agar extraction from integrated multitrophic aquacultured Gracilaria vermiculophylla: evaluation of a microwave-assisted process using response surface methodology, Bioresour. Technol. 101 (2010) 3258-3267, https://doi.org/10.1016/j. biortech.2009.12.061.

[9] J.S. Maciel, L.S. Chaves, B.W.S. Souza, D.I.A. Teixeira, A.L.P. Freitas, J.P.A. Feitosa, R.C.M. de Paula, Structural characterization of cold extracted fraction of soluble sulfated polysaccharide from red seaweed Gracilaria birdiae, Carbohydr. Polym. 71 (2008) 559-565, https://doi.org/10.1016/j.carbpol.2007.06.026.

[10] E. Conde, E.M. Balboa, M. Parada, E. Falqué, Algal Proteins, Peptides and Amino Acids, 2013, https://doi.org/10.1533/9780857098689.1.135.

[11] M. Tabarsa, M. Rezaei, Z. Ramezanpour, J.R. Waaland, Chemical compositions of the marine algae Gracilaria salicornia (Rhodophyta) and Ulva lactuca (Chlorophyta) as a potential food source, J. Sci. Food Agric. 92 (2012) 2500-2506, https://doi.org/10.1002/jsfa.5659.

[12] Y.E. Rodríguez-Montesinos, D.L. Arvizu-Higuera, G. Hernández-Carmona, M. Muñoz-Ochoa, J.I. Murillo-Álvarez, Seasonal variation of the agar quality and chemical composition of Gracilaria veleroae and Gracilaria vermiculophylla (Rhodophyceae, Gracilariaceae) from Baja California Sur, Mexico, Phycol. Res. 61 (2013) 116-123, https://doi.org/10.1111/pre.12008.

[13] P.T. Chan, P. Matanjun, Chemical composition and physicochemical properties of tropical red seaweed, Gracilaria changii, Food Chem. 221 (2017) 302-310, https:// doi.org/10.1016/j.foodchem.2016.10.066.

[14] T. Rosemary, A. Arulkumar, S. Paramasivam, A. Mondragon-Portocarrero, J. M. Miranda, Biochemical, micronutrient and physicochemical properties of the dried red seaweeds gracilaria edulis and gracilaria corticata, Molecules. 24 (2019) 1-15, https://doi.org/10.3390/molecules24122225.

[15] S. Charoensiddhi, M.A. Conlon, C.M.M. Franco, W. Zhang, The development of seaweed-derived bioactive compounds for use as prebiotics and nutraceuticals using enzyme technologies, Trends Food Sci. Technol. 70 (2017) 20-33, https:// doi.org/10.1016/j.tifs.2017.10.002.

[16] M. Martins, F.A. Vieira, I. Correia, R.A.S. Ferreira, H. Abreu, J.A.P. Coutinho, S.P. M. Ventura, Recovery of phycobiliproteins from the red macroalga: Gracilaria sp. using ionic liquid aqueous solutions, Green Chem. 18 (2016) 4287-4296, https:// doi.org/10.1039/c6gc01059h.

[17] E. Mendis, S.K. Kim, Present and Future Prospects of Seaweeds in Developing Functional Foods, 1st ed., Elsevier Inc, 2011 https://doi.org/10.1016/B978-0-12387669-0.00001-6.

[18] W.K. Lee, Y.Y. Lim, A.T.C. Leow, P. Namasivayam, J.O. Abdullah, C.L. Ho, Factors affecting yield and gelling properties of agar, J. Appl. Phycol. 29 (2017) 1527-1540, https://doi.org/10.1007/s10811-016-1009-y.

[19] R.D. Villanueva, A.M.M. Sousa, M.P. Gonçalves, M. Nilsson, L. Hilliou, Production and properties of agar from the invasive marine alga, Gracilaria vermiculophylla (Gracilariales, Rhodophyta), J. Appl. Phycol. 22 (2010) 211-220, https://doi.org/ 10.1007/s10811-009-9444-7.

[20] H.P.S. Abdul Khalil, T.K. Lai, Y.Y. Tye, S. Rizal, E.W.N. Chong, S.W. Yap, A. A. Hamzah, M.R. Nurul Fazita, M.T. Paridah, A review of extractions of seaweed hydrocolloids: properties and applications, Express Polym Lett 12 (2018) 296-317, https://doi.org/10.3144/expresspolymlett.2018.27. 
[21] K. Balina, F. Romagnoli, D. Blumberga, Seaweed biorefinery concept for sustainable use of marine resources, Energy Procedia 128 (2017) 504-511, https:// doi.org/10.1016/j.egypro.2017.09.067.

[22] M. Álvarez-Viñas, N. Flórez-Fernández, M.D. Torres, H. Domínguez, Successful approaches for a red seaweed biorefinery, Mar. Drugs 17 (2019), https://doi.org/ 10.3390/md17110620.

[23] R.N. Pereira, A.A. Vicente, Environmental impact of novel thermal and nonthermal technologies in food processing, Food Res. Int. 43 (2010) 1936-1943, https://doi.org/10.1016/j.foodres.2009.09.013.

[24] C. Kusnadi, S.K. Sastry, Effect of moderate electric fields on salt diffusion into vegetable tissue, J. Food Eng. 110 (2012) 329-336, https://doi.org/10.1016/j. jfoodeng.2012.01.004.

[25] I. Castro, B. Macedo, J.A. Teixeira, A.A. Vicente, The effect of electric field on important food-processing enzymes: comparison of inactivation kinetics under conventional and ohmic heating, J. Food Sci. 69 (2006) C696-C701, https://doi. org/10.1111/j.1365-2621.2004.tb09918.x.

[26] R.N. Pereira, R.M. Rodrigues, Z. Genisheva, H. Oliveira, V. de Freitas, J.A. Teixeira, A.A. Vicente, Effects of ohmic heating on extraction of food-grade phytochemicals from colored potato, LWT Food Sci. Technol. 74 (2016) 493-503, https://doi.org/ 10.1016/j.lwt.2016.07.074.

[27] R.M. Rodrigues, A.J. Martins, O.L. Ramos, F.X. Malcata, J.A. Teixeira, A.A. Vicente, R.N. Pereira, Influence of moderate electric fields on gelation of whey protein isolate, Food Hydrocoll. 43 (2015) 329-339, https://doi.org/10.1016/j. foodhyd.2014.06.002.

[28] E.G. Bligh, W.J. Dyer, A rapid method of total lipid extraction and purification, Can. J. Biochem. Physiol. 37 (1959).

[29] P. Bernfeld, Enzymes of starch degradation and synthesis, Adv. Enzymol. Relat. Areas Mol. Biol. 12 (1951), https://doi.org/10.1002/9780470122570.ch7.

[30] M. Kazir, Y. Abuhassira, A. Robin, O. Nahor, J. Luo, A. Israel, A. Golberg, Y. D. Livney, Extraction of proteins from two marine macroalgae, Ulva sp. and Gracilaria sp., for food application, and evaluating digestibility, amino acid composition and antioxidant properties of the protein concentrates, Food Hydrocoll. 87 (2019) 194-203, https://doi.org/10.1016/j.foodhyd.2018.07.047.

[31] T.T. Stevenson, R.H. Furneaux, Chemical methods for the analysis of sulphated galactans from red algae, Carbohydr. Res. 210 (1991) 277-298, https://doi.org/ 10.1016/0008-6215(91)80129-B.

[32] M.A. Coimbra, K.W. Waldron, R.R. Selvendran, Isolation and characterisation of cell wall polymers from olive pulp (Olea europaea L.), Carbohydr. Res. 252 (1994) 245-262, https://doi.org/10.1016/0008-6215(94)90019-1.

[33] Y. Wang, Y. Jing, F. Leng, S. Wang, F. Wang, Y. Zhuang, X. Liu, X. Wang, X. Ma, Establishment and application of a method for rapid determination of total sugar content based on colorimetric microplate, Sugar Tech. 19 (2017) 424-431, https:// doi.org/10.1007/s12355-016-0473-7.

[34] O. Lowry, N. Rosebrough, A.L. Farr, R.J. Randall, Protein measurement with the folin phenol reagent, J. Biol. Chem. 193 (1951) 265-275.

[35] C.I. Teixeira-Guedes, D. Oppolzer, A.I. Barros, C. Pereira-Wilson, Impact of cooking method on phenolic composition and antioxidant potential of four varieties of Phaseolus vulgaris L. and Glycine max L, LWT Food Sci. Technol. 103 (2019) 238-246, https://doi.org/10.1016/j.lwt.2019.01.010.

[36] H.K. Lichtenthaler, C. Buschmann, Chlorophylls and carotenoids: measurement and characterization by UV-VIS spectroscopy, Curr. Protoc. Food Anal. Chem. 2-2 (2001) 171-178, https://doi.org/10.1002/0471709085.ch21.

[37] A.A.S. Bolanos de la Torre, T. Henderson, P.S. Nigam, R.K. Owusu-Apenten, A Universally Calibrated Microplate Ferric Reducing Antioxidant Power (FRAP) Assay For Foods and Applications to Manuka Honey, 2015, https://doi.org/ 10.1016/j.foodchem.2014.11.009.

[38] K.H. Sabeena Farvin, C. Jacobsen, Phenolic compounds and antioxidant activities of selected species of seaweeds from Danish coast, Food Chem. 138 (2013) 1670-1681, https://doi.org/10.1016/j.foodchem.2012.10.078.

[39] B.W.S. Souza, M.A. Cerqueira, A.I. Bourbon, A.C. Pinheiro, J.T. Martins, J. A. Teixeira, M.A. Coimbra, A.A. Vicente, Chemical characterization and antioxidant activity of sulfated polysaccharide from the red seaweed Gracilaria birdiae, Food Hydrocoll. 27 (2012) 287-292, https://doi.org/10.1016/j. foodhyd.2011.10.005.

[40] A. Rotem, N. Roth-Bejerano, S. (Malis) Arad, Effect of controlled environmental conditions on starch and agar contents of Gracilaria Sp. (Rhodophyceae), J. Phycol. 22 (1986) 117-121, https://doi.org/10.1111/j.1529-8817.1986.tb04153.x.
[41] H. Admassu, M.A.A. Gasmalla, R. Yang, W. Zhao, Bioactive peptides derived from seaweed protein and their health benefits: antihypertensive, antioxidant, and antidiabetic properties, J. Food Sci. 83 (2018) 6-16, https://doi.org/10.1111/ 1750-3841.14011.

[42] Y. Llave, S. Fukuda, M. Fukuoka, N. Shibata-Ishiwatari, N. Sakai, Analysis of color changes in chicken egg yolks and whites based on degree of thermal protein denaturation during ohmic heating and water bath treatment, J. Food Eng. 222 (2018) 151-161, https://doi.org/10.1016/j.jfoodeng.2017.11.024.

[43] L. Beaulieu, M. Sirois, É. Tamigneaux, Evaluation of the in vitro biological activity of protein hydrolysates of the edible red alga, Palmaria palmata (dulse) harvested from the Gaspe coast and cultivated in tanks, J. Appl. Phycol. 28 (2016) 3101-3115, https://doi.org/10.1007/s10811-016-0850-3.

[44] A. Naseri, G.S. Marinho, S.L. Holdt, J.M. Bartela, C. Jacobsen, Enzyme-assisted extraction and characterization of protein from red seaweed Palmaria palmata, Algal Res. 47 (2020), 101849, https://doi.org/10.1016/j.algal.2020.101849.

[45] H. Harrysson, M. Hayes, F. Eimer, N.G. Carlsson, G.B. Toth, I. Undeland, Production of protein extracts from Swedish red, green, and brown seaweeds, Porphyra umbilicalis Kützing, Ulva lactuca Linnaeus, and Saccharina latissima (Linnaeus) J. V. Lamouroux using three different methods, J. Appl. Phycol. 30 (2018) 3565-3580, https://doi.org/10.1007/s10811-018-1481-7.

[46] S. Bleakley, M. Hayes, Algal proteins: extraction, application, and challenges concerning production, Foods. 6 (2017) 33, https://doi.org/10.3390/ foods 6050033.

[47] A. Tamayo Tenorio, K.E. Kyriakopoulou, E. Suarez-Garcia, C. van den Berg, A.J. van der Goot, Understanding differences in protein fractionation from conventional crops, and herbaceous and aquatic biomass - consequences for industrial use, Trends Food Sci. Technol. 71 (2018) 235-245, https://doi.org/10.1016/j. tifs.2017.11.010.

[48] F. Liu, C. Ma, Y. Gao, D.J. McClements, Food-grade covalent complexes and their application as nutraceutical delivery systems: a review, Compr. Rev. Food Sci. Food Saf. 16 (2017) 76-95, https://doi.org/10.1111/1541-4337.12229.

[49] C.M.R. Rocha, Z. Genisheva, P. Ferreira-Santos, R. Rodrigues, A.A. Vicente, J. A. Teixeira, R.N. Pereira, Electric field-based technologies for valorization of bioresources, Bioresour. Technol. 254 (2018) 325-339, https://doi.org/10.1016/j. biortech.2018.01.068.

[50] M. Aamir, W. Jittanit, Ohmic heating treatment for Gac aril oil extraction: effects on extraction efficiency, physical properties and some bioactive compounds, Innov. Food Sci. Emerg. Technol. 41 (2017) 224-234, https://doi.org/10.1016/j. ifset.2017.03.013.

[51] P. Ferreira-Santos, Z. Genisheva, R.N. Pereira, J.A. Teixeira, C.M.R. Rocha, Moderate electric fields as a potential tool for sustainable recovery of phenolic compounds from Pinus pinaster bark, ACS sustain, Chem. Eng. 7 (2019) 8816-8826, https://doi.org/10.1021/acssuschemeng.9b00780.

[52] A.L. Pina, A.R. Costa, M.A. Lage-Yusty, J. López-Hernández, An evaluation of edible red seaweed (Chondrus crispus) components and their modi fi cation during the cooking process, LWT - food Sci, Technol. 56 (2014) 175-180, https://doi.org/ 10.1016/j.lwt.2013.08.006.

[53] R.S. Rasmussen, M.T. Morrissey, Marine biotechnology for production of food ingredients, Adv. Food Nutr. Res. 52 (2007) 237-292, https://doi.org/10.1016/ S1043-4526(06)52005-4.

[54] T. Wang, R. Jónsdóttir, G. Ólafsdóttir, Total phenolic compounds, radical scavenging and metal chelation of extracts from Icelandic seaweeds, Food Chem. 116 (2009) 240-248, https://doi.org/10.1016/j.foodchem.2009.02.041.

[55] R. Armisen, World-wide use and importance of Gracilaria, J. Appl. Phycol. 7 (1995) 231-243, https://doi.org/10.1007/BF00003998.

[56] A.M.M. Sousa, J. Borges, A.F. Silva, M.P. Gonçalves, Influence of the extraction process on the rheological and structural properties of agars, Carbohydr, Polym. 96 (2013) 163-171, https://doi.org/10.1016/j.carbpol.2013.03.070.

[57] A.M.M. Sousa, S. Morais, M.H. Abreu, R. Pereira, I. Sousa-Pinto, E.J. Cabrita, C. Delerue-Matos, M.P. Gonçalves, Structural, physical, and chemical modifications induced by microwave heating on native agar-like galactans, J. Agric. Food Chem. 60 (2012) 4977-4985, https://doi.org/10.1021/jf2053542.

[58] M.R.S. Melo, J.P.A. Feitosa, A.L.P. Freitas, R.C.M. De Paula, Isolation and characterization of soluble sulfated polysaccharide from the red seaweed Gracilaria cornea, Carbohydr. Polym. 49 (2002) 491-498, https://doi.org/10.1016/S01448617(02)00006-1. 